Volume 2, Issue 1-2 (Summer 2010)

\title{
The Art of Nikolaus Glockendon: Imitation and Originality in the Art of Renaissance Germany
}

Debra Taylor Cashion

Recommended Citation:

Debra Taylor Cashion, "The Art of Nikolaus Glockendon: Imitation and Originality in the Art of Renaissance Germany, JHNA 2:1-2 (2010), DOI: 10.5092/jhna.2010.2.1.2

Available at https://jhna.org/articles/art-nikolaus-glockendon-imitation-originality-art-renaissance-germany/

Published by Historians of Netherlandish Art: https://hnanews.org/

Republication Guidelines: https://jhna.org/republication-guidelines/

Notes: This PDF is provided for reference purposes only and may not contain all the functionality or features of the original, online publication. This is a revised PDF that may contain different page numbers from the previous version. Use electronic searching to locate passages. This PDF provides paragraph numbers as well as page numbers for citation purposes.

ISSN: 1949-9833 


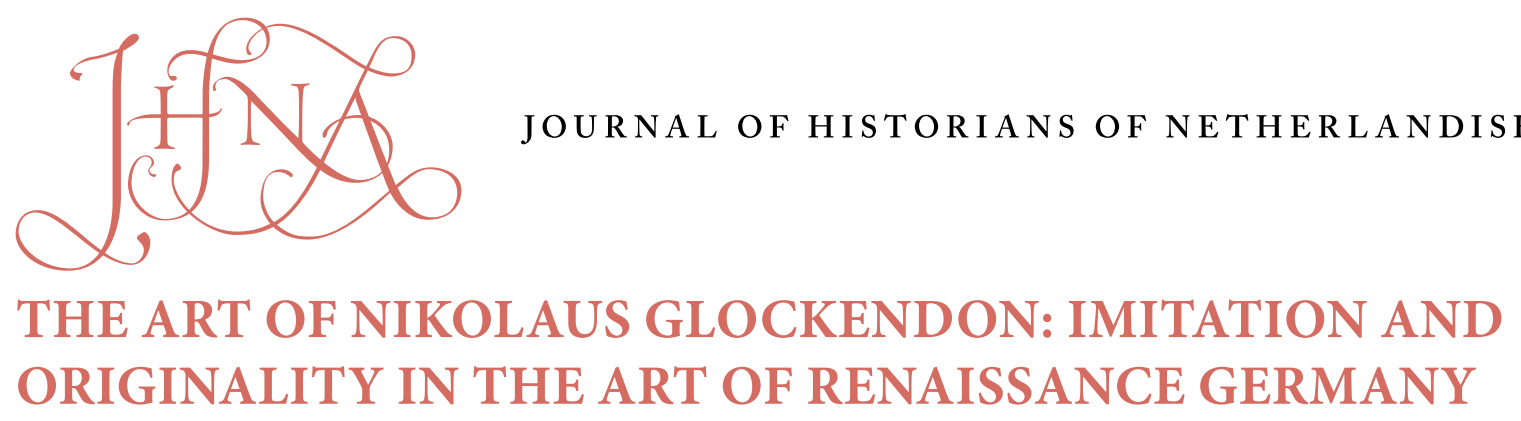

\section{Debra Taylor Cashion}

Nikolaus Glockendon (ca. 1490/95-1533/34), the foremost illuminator of sixteenth-century Germany, made a career of copying the compositions of other artists, especially those of his Nuremberg contemporary Albrecht Dürer. Like Dürer, Glockendon was the acknowledged German master in his field, supported by elite patronage and impressively high fees, with a productivity attested to by a large body of identified works. This paper contextualizes Glockendon's imitative practice within the traditions of medieval art, the hierarchy of style in late medieval literature, the practice of finishing in illuminated manuscripts, the entrepreneurial trends in book illustration after the invention of printing, the contemporary conceptions of artistic property and conventions of exchange, and the documented standards of value in sixteenth-century German craftsmanship. D01: 10.5092/jhna.2010.2.1.2

\section{The Cardinal's “Musician"}

mong the masterpieces of German Renaissance art is an illuminated manuscript in the
Hofbibliothek at Aschaffenburg. Preserved in its original sixteenth-century binding,
embellished with engraved vermeil plaquettes and gold and silver page-markers, Ms.10 is an intentionally magnificent ceremonial missal decorated with sumptuously painted borders, an illustrated calendar, ninety-three historiated initials, and twenty-three full-page miniatures (fig.1). ${ }^{1}$

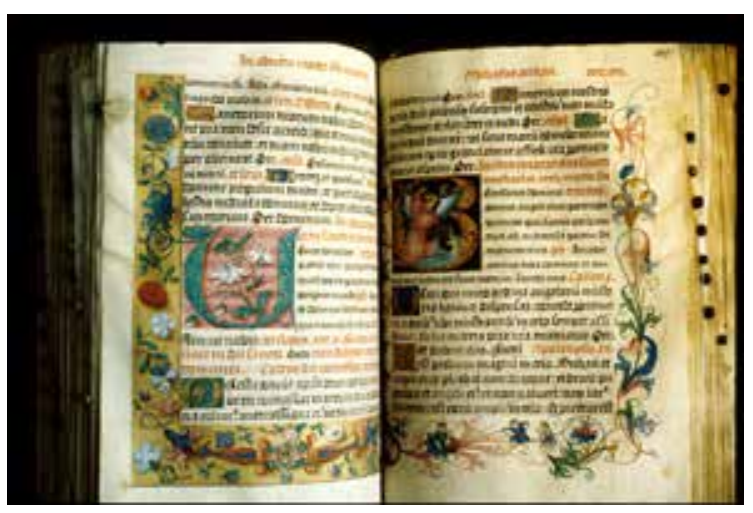

Fig. 1 Nikolaus Glockendon, Missale Hallense of Albrecht of Brandenburg, 1524, Aschaffenburg, Hofbibliothek, Ms. 10, fols. 440v-441 (artwork in the public domain)

Made for Cardinal Albrecht of Brandenburg (1490-1545), the Missale Hallense (a missal for the cardinal's church at Halle) not only attests to the extravagant tastes of its patron but also demonstrates the masterful skill of its maker, Nikolaus Glockendon of Nuremberg (ca.1490/951533/34). ${ }^{2}$ The foremost German illuminator of his generation, Glockendon belonged to a family 
of Nuremberg artists who for at least three generations worked in illuminated manuscripts, painted coats of arms, prints, publishing, and cartography. ${ }^{3}$ Nikolaus Glockendon signed and dated the Missale Hallense in 1524 and, it has been suggested, may have included an image of himself in one of the full-page miniatures, that of the Corpus Christi Procession (fig. 2). ${ }^{4}$ In this documentary-style depiction of the celebrations for a sacred feast day, a figure of a finely dressed court musician, plucking the strings of a small harp, gazes directly at the viewer, as if to invite us to join the throng of worshipers as they approach the entrance of the church. The engaging harpist and his companions herald the arrival of the procession as well as announce the ultimate purpose of the manuscript: the unabashed celebration of the patron, who marches as presiding bishop and carries a gold monstrance underneath a liturgical canopy. Although the identity of the harpist is only conjectural, that of the bishop is beyond doubt, as portraits of Cardinal Albrecht are ubiquitous: on the front cover in gilded relief, on the inside front flyleaf as an ex libris, in several full-page miniatures depicting his spiritual leadership, and among the historiated initials, where he is presented in prayer. Albrecht's presence is also proclaimed through his plentiful coats of arms, emblazoned separately in the borders of dozens of text pages, or combined in a full-page display of rank and title flanked by his patron saints, Maurice and Mary Magdalene (fig. 3). Perusing the manuscript, the student of Renaissance art recognizes the signs of a wealthy and powerful patron placing personal aggrandizement ahead of the religious function of the work. But the lavish decoration of the Missale Hallense proclaims another, more sympathetic motivation shared by patron and artist, that is, to produce a stunning example of book craft.
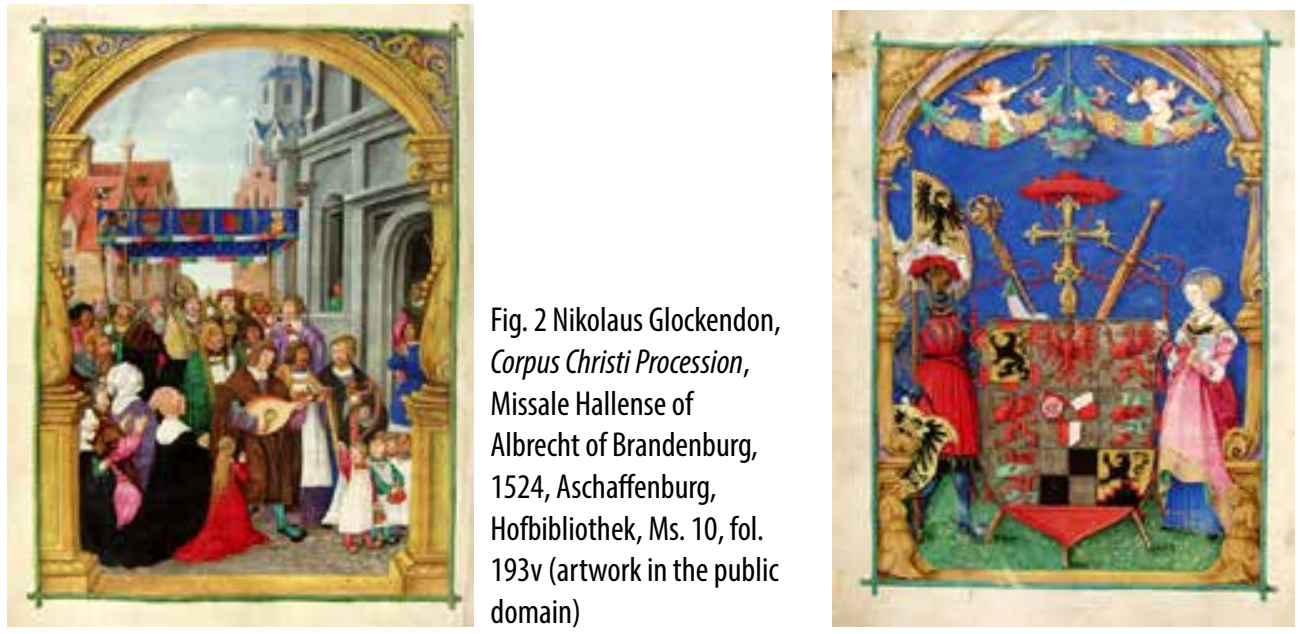

Fig. 3 Nikolaus Glockendon, Coats of Arms of Albrecht of Brandenburg, Missale Hallense of Albrecht of Brandenburg, 1524, Aschaffenburg, Hofbibliothek, Ms. 10, fol. 07v (artwork in the public domain)

The significance of the Missale Hallense can be measured in economic as well as artistic terms. For this single commission Glockendon received a payment of 500 gulden, a fee so noteworthy that the mathematician, calligrapher, and author Johann Neudörfer refers to it in his 1547 Nachrichten von Künstlern und Werkleuten, a biographical record of Nuremberg artists and artisans. ${ }^{5}$ Neudörfer, who considered Glockendon "mein lieber Freund" (my dear Friend), adds that Glockendon was a "fertig" (skilled) and "fleissig" (diligent) illuminator who received "auch sonst viel Fürstenarbeit" (a great number of other princely commissions). ${ }^{6}$ These included not only further work for Albrecht of Brandenburg but also for Duke Johann Friedrich of Saxony, Duke Albrecht of Prussia, the Nuremberg city council, and wealthy patrician families such as Imhoff and Tucher. The Missale Hallense thus represents the centerpiece of a large body of work that to date includes at least thirty bound manuscripts and twenty-three single leaves. ${ }^{7}$ 
Although Neudörfer sought to valorize Glockendon's achievements for posterity, more recent studies of Nuremberg art have associated Glockendon with the Nuremberg Kleinmeister, i.e., the Nuremberg-centered artists who propagated the style of Albrecht Dürer. ${ }^{8}$ Although the term Kleinmeister is more applicable to the generation of Nuremberg artists known for their small-scale prints, including Sebald Beham, Barthel Beham, and George Pencz, the notion of Glockendon as follower is reasonable because he frequently borrowed compositions from Dürer as well as from other artists. ${ }^{9}$ The main objective of this paper, however, is to reconsider Glockendon's imitative works within his artistic and cultural context and examine the circumstances in which those works were produced and received. I am especially interested in his relationship to Dürer, an artist recognized for his self-conscious originality and assertive efforts to protect his work from piracy. ${ }^{10}$

Glockendon was not a pupil or later follower of Dürer, but a contemporary and colleague, whose relationship to Nuremberg's most famous artist is documented by correspondence concerning the Missale Hallense. In 1523, when Glockendon was at work on Cardinal Albrecht's missal, Dürer served as mediator between his colleague and their mutual patron, who apparently had sent an anxious request to Dürer for a report on the illuminator's progress. In a letter dated September 4 of that year, Dürer explains to the cardinal that the major impediment to the completion of the manuscript is the patron's delay in payments. Sympathetic to Glockendon's predicament, Dürer makes a diplomatic appeal for further funding:

...Most gracious lord, on receipt of your gracious letter and request, I at once went to Nikolaus Glockendon about the missal, according to your gracious command. He has not yet got it finished, and he told me that he has still seven large subjects to paint, as well as seven of the largest initials. He would not fix me any definite time when they would be ready. He said that unless some more money were sent him he must lay aside your Grace's work for want of food, and take something else in hand for he has nothing in the house for his necessities. I could do no more with him in the matter except urge him to carry on the work as far as possible, etc. ${ }^{11}$

6 Dürer's letter indicates a cordial working relationship between the two artists and suggests that Dürer witnessed the production of the Missale Hallense in Glockendon's shop. This evidence is supported by a 1523 dated drawing by Dürer in Berlin, which served as the immediate model for Glockendon's full-page miniature of Cardinal Albrecht assisting at a mass celebrated by another bishop..$^{12}$ The preparatory drawing by Dürer not only attests to the extraordinary customization of the cardinal's manuscript but also establishes the context for Glockendon's use of Dürer's compositions, which he must have borrowed with Dürer's knowledge and consent. Throughout the Missale Hallense, one recognizes illuminated versions of works of art by Dürer, including twenty-four woodcuts, nine engravings, three drawings, and two panel paintings. ${ }^{13}$ In the same manuscript Glockendon borrows from prints by Lucas Cranach, Hans Burgkmair, and Martin Schongauer as well as from miniatures by Simon Bening and Jakob Elsner. ${ }^{14}$ In most cases, Glockendon makes no effort to disguise his source but transforms and interprets it through the masterful handling of pigments. 
Glockendon's ability as a colorist deserves mention. In the initials and miniatures of the Missale Hallense he employs one of the richest palettes in the whole of German Renaissance painting. James Marrow, the first American scholar to consider Glockendon's work, has noted the illuminator's copies of miniatures by Simon Bening, who also worked on manuscript commissions from Cardinal Albrecht. ${ }^{15}$ The calendar of the Missale Hallense depends on Bening, and throughout the manuscript one recognizes the reception of Flemish elements, including border decoration in the Streublumen, or strewn-flower style, framing miniatures such as The Trinity (fig. 4). These were likely introduced to him through the work of Jakob Elsner, whose missal for Anton Kress provided the model for The Trinity (fig. 5). ${ }^{16}$ One can perceive Netherlandish influence in both of these miniatures, which employ the courtly palette of Bruges painting, including rich reds and blues reminiscent of Jan van Eyck. But Glockendon enlivens these with the secondary and tertiary colors associated with Bohemian painting to create a sumptuous interplay of varied and unexpected hues, producing a greater sense of volume and atmospheric space, with only a little reliance on linear perspective. In the miniature The Resurrection (fig. 6), Glockendon closely replicates Dürer's woodcut of the same subject from the so-called Large Passion (fig. 7), but a comparison between the two works reveals how Glockendon's exuberant use of color achieves a sense of celebration through shading, gold highlights, and bright hues.
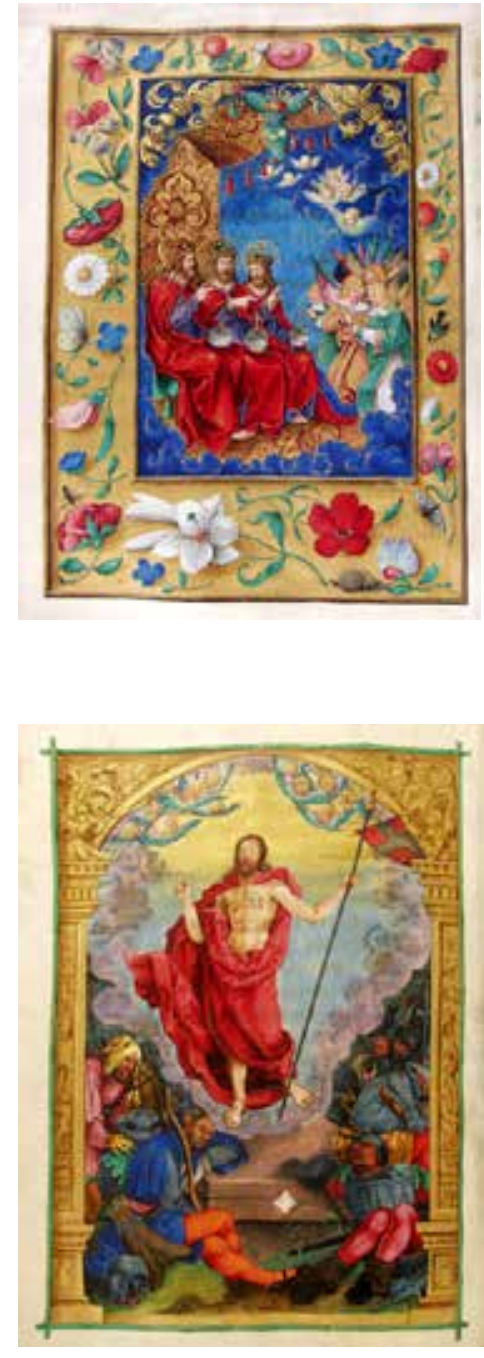

Fig. 6 Nikolaus Glockendon, The Resurrection, Missale Hallense of Albrecht of Brandenburg, 1524, Aschaffenburg, Hofbibliothek, Ms. 10, fol. 153v (artwork in the public domain)

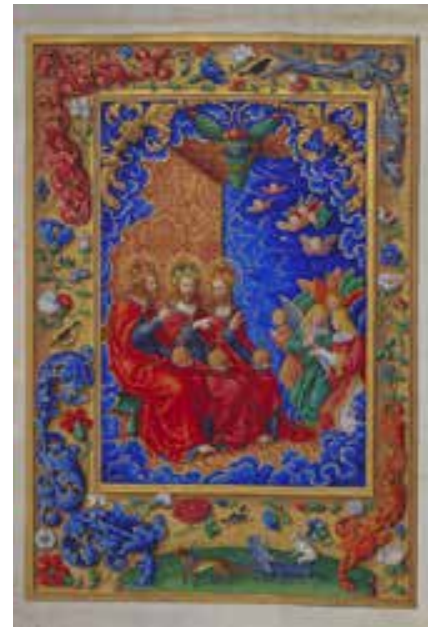

Fig. 5 Jakob Elsner, The Trinity, Kress Missal, 1513, Nuremberg, Germanisches Nationalmuseum, Hs. 113264, fol. 2v (artwork in the public domain)

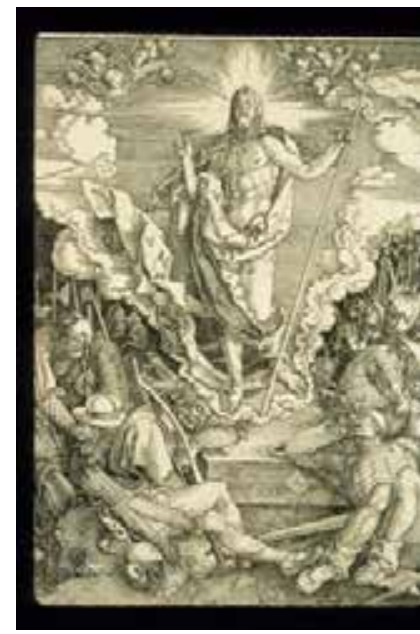

Fig. 7 Albrecht Dürer, The Resurrection (Large Passion), woodcut, 1510, Museum of Fine Arts, Boston, Bequest of Francis Bullard (Photo @ 2010 Museum of Fine Arts Boston)(artwork in the public domain) 
Glockendon's rendition of The Resurrection from Dürer's Large Passion recalls his possible alter ego as musician in the Corpus Christi miniature. In Glockendon's hands Dürer's authoritative composition becomes an accomplished performance, rephrased and reinterpreted by an artist of different training and sensibility. Evidence suggests that Cardinal Albrecht valued the performative aspect of imitation, especially as pertaining to manuscript illumination. Between about 1525 and 1537 he commissioned three manuscript versions of the same printed book, illustrated with woodcuts by Hans Weiditz, from Simon Bening, Nikolaus Glockendon, and Gabriel Glockendon, respectively. ${ }^{17}$ Nikolaus Glockendon's version appears to be a response to Bening's, and Gabriel Glockendon's version seems to follow his father's. Comparison of the illustrations by all four artists reveals variations to this pattern, but in several instances images of the same subject appear to be related according to a progression in which a theme is stated by Weiditz, rearranged by Bening, re-interpreted by Nikolaus Glockendon, and refined by Gabriel Glockendon (figs. 8-11). ${ }^{18}$ The compositions of seven miniatures from Nikolaus Glockendon's version are repeated in a series of drawings attributed to the Nuremberg stained glass painter Augustin Hirschvögel. ${ }^{19}$ Rather than copies, one might justifiably consider such a series of interdependent works of the same subject as musical variations on a theme.

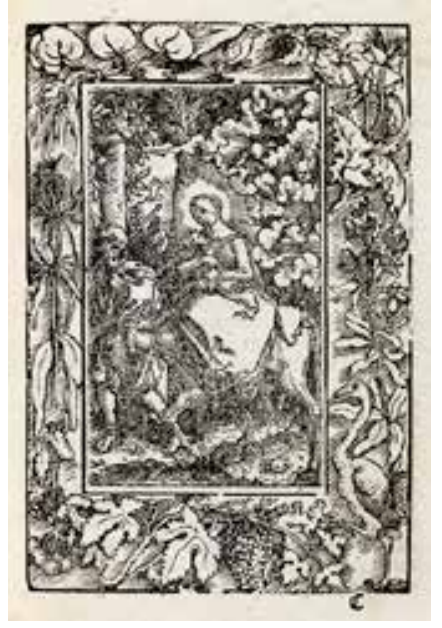

Fig. 8 Hans Weiditz, The Flight Into Egypt, woodcut (Augsburg, Sigmund Grim and Marx Wyrsung [sic], 1520), Cambridge University Library, SSS.54.36 (artwork in the public domain)

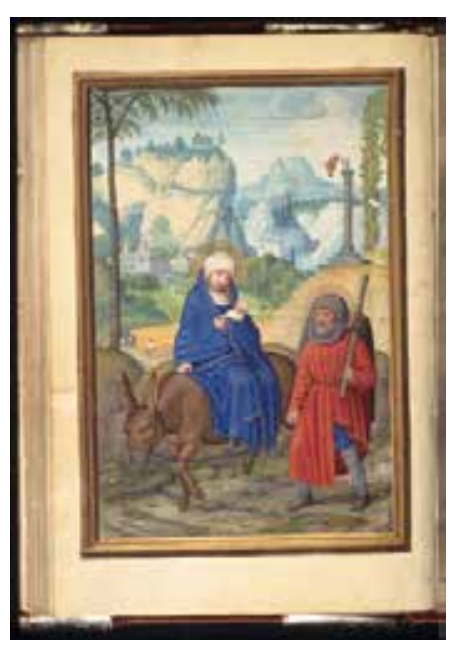

Fig. 9 Simon Bening, The Flight into Egypt, Prayer Book of Albrecht of Brandenburg, ca. 1525-30, Los Angeles, J. Paul Getty Museum, 83.ML.115 (formerly Ms. Ludwig IX 19), fol. 47v (artwork in the public domain)

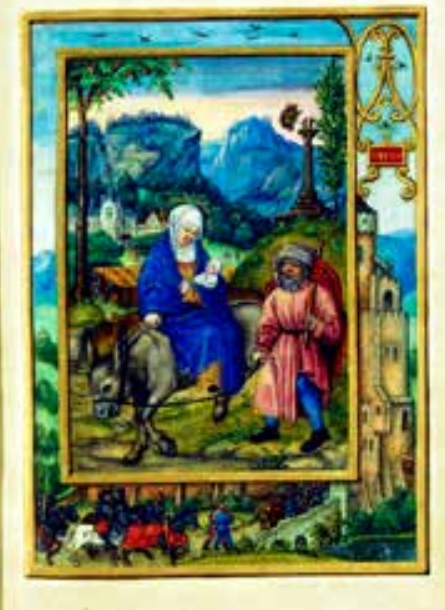

Fig. 10 Nikolaus Glockendon, The Flight into Egypt, Passion Prayer Book of Albrecht of Brandenburg, ca. 1533/34, Modena, Biblioteca Estense, Ms. Est. 136 (formerly Ms. alpha.U.6.7), fol. 20 (artwork in the public domain)

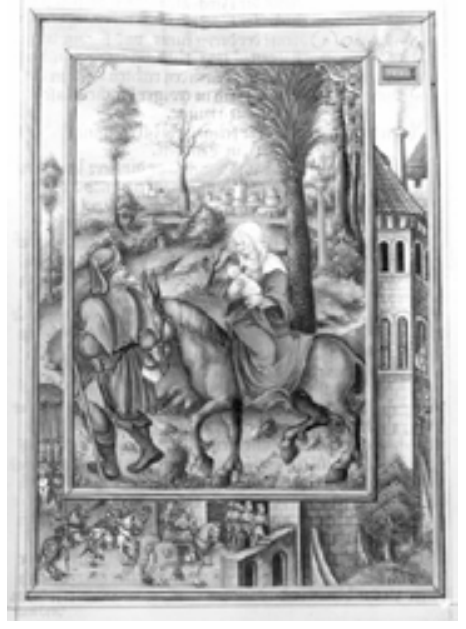

Fig. 11 Gabriel Glockendon, The Flight into Egypt, Prayer Book of Albrecht of Brandenburg, 1537, Vienna, Österreichische Nationalbibliothek, Cod. 1847, fol. $13 \mathrm{v}$ (artwork in the public domain) 
In his book on German limewood sculpture Michael Baxandall uses a musical paradigm to discuss the issue of artistic originality in this period. As an illustrative example, Baxandall outlines the theory of Mastersong, the popular art form of the Nuremberg Meistersinger. ${ }^{20}$ The Meistersinger contributed to their art by writing new words to old melodies, or Töne, until the 1480s, when "the invention of new personal Töne became more and more the mark of the master." ${ }^{21}$ But even after the notion of original Töne gained acceptance, Masters, including the famous Hans Sachs, continued to replicate the classic old Töne as well as the melodies of their contemporaries and their own melodies, over and over again.

10 Like his contemporary Hans Sachs, Nikolaus Glockendon was capable of creating (and did create) his own compositions. But he preferred to work with pre-established compositions rather than continually to invent new ones. Baxandall explains the standard: "Mastery is the capacity to invent new patterns, and patterns are associated with their inventors; the master will propagate his own pattern, but will feel no shame about using other men's, particularly the classic ones of the past; lesser practitioners may well settle for working within forms originated by others; the adopting as well as the inventing of patterns is open and avowed." 22

11 An interesting aspect of this standard is its lack of exclusivity: a master is recognized by his inventions, but they do not constitute inviolable territory. Masters make patterns meant to be copied. Dürer was the acknowledged master of painting in Nuremberg. His compositions were understood to serve as authoritative models for his contemporaries. Glockendon, the acknowledged master of Nuremberg illumination, also produced compositions that served as models for artists such as Augustin Hirschvogel. These artists participated in an artistic tradition that valued interpretation and continuity over invention.

12 Glockendon's Missale Hallense, like many masterpieces, whether visual or musical, impresses us with its virtuosity and its fashioning of ambitious patronage. But its technical brilliance challenges us to consider the tacit assumptions we hold and the judgments we make about imitation in Glockendon's art. How do we understand Glockendon as an artist? He participated in the same culture, lived in the same town, and enjoyed the same patronage as Albrecht Dürer, an artist described as "possessed by an original idea of originality per se." 23 Should Glockendon's dependence on the work of Dürer and other artists count against him when measuring his artistic accomplishment? Are there universal reasons for artistic imitation or can we discern these as particular to an artist's historical context, as Baxandall's paradigm suggests?

13 This paper will examine Glockendon's artistic and cultural circumstances in order to better understand the motivations for imitation in his art. It will show that the art and literature of the period employed imitation as normative practice, and that copies and masterpieces in various media were not mutually exclusive works. It will review how printing created a new artistic environment for replication, reconsider Erwin Panofsky's scholarship that brought prints and German art into the art historical canon, and reevaluate the significance of Albrecht Dürer's imperial privilege to protect his prints as intellectual property. It will also consider the status of the designing artist and investigate the standards of value for artistic achievement outlined in Johann Neudörfer's Nachrichten. Ultimately it will reveal a conception of artistic property more tangible than intellectual 
and re-associate the art of Nikolaus Glockendon and the German Renaissance with the journeyman trades and the manipulation of materials rather than with the tenaciously romantic notion of art as self-expression determined by originality or genius.

\section{Veronica's Veil}

14 To develop an understanding of imitation in Nikolaus Glockendon's work, we must first recognize any manuscript illuminator as heir to a tradition that thrived on copies and made no demands on artists to produce something new. ${ }^{24}$ Furthermore, we must consider the evidence that medieval viewers held invention suspect. Epiphanius of the fourth century, for example, criticizes artists who "lie by representing the appearance of saints in different form according to their whims" and condemns images "set down through the stupidity of the painter...according to his own inclination." ${ }^{25}$ As Epiphanius implies, replication was fundamental to the medieval artist's task: to evoke the sacred authority of established prototypes.

15 In his classic study of architectural copies of the Church of the Holy Sepulchre in Jerusalem, Richard Krautheimer supports this view and explains that the power of medieval prototypes was both tangible and intangible: "Both immaterial and visual elements are intended to be an echo of the original capable of reminding the faithful of a venerated site, of evoking his devotion and of giving him a share at least in the reflections of the blessings which he would have enjoyed if he had been able to visit the Holy Site in reality." ${ }^{26}$

16 Medieval imitations of the Holy Sepulchre presupposed an essential optimism that allowed a replica shrine to serve spiritual functions in place of an original exemplar. The churches studied by Krautheimer not only imitated the architectural forms of the Church of the Holy Sepulchre but also included replicas of the tomb of Christ and copies of sacred relics actually preserved in Jerusalem. ${ }^{27}$ A similar sort of a replica shrine was the most important pilgrimage site in late medieval England-not Canterbury, but the shrine to the Virgin at Little Walsingham, where a stone chapel enclosed an acknowledged replica of the Virgin Mary's own home. ${ }^{28}$ In late fifteenth-century Augsburg, the nuns of St. Katherine's commissioned a cycle of paintings for the walls of their chapter house, in order to simulate a pilgrimage to the seven churches of Rome. Confined to their convent because of the vow of enclosure, they nevertheless received the same papal indulgences for visiting their painted surrogates as did a pilgrim to the actual churches. ${ }^{29}$

17 Even in the case of relics what Walter Benjamin refers to as the "aura" or unique presence of an object was nevertheless transferable to a medieval copy, and a recognized imitation could become as sanctified and venerated as an "original." ${ }^{30}$ In Byzantium, pilgrims to holy sites brought home eulogia, amulets that contained holy oil and displayed replicas of wonder-working icons that had themselves become equivalent to relics. ${ }^{31}$ Replicas were also in demand at the fairs of Chartres, where one could purchase copies of the cathedral's most sacred relic, the tunic of the Virgin. Pilgrims then wore these chemisettes for protection during childbirth or battle. ${ }^{32}$ A whole genre of pilgrimage manuals developed in the fifteenth century which, like the painting cycle at St. Katherine's of Augsburg, allowed readers to make a spiritual pilgrimage without leaving home. These manuals, such as one written for the nuns at Windesheim, substituted the mere description of relics for their actual presence and granted indulgences to the reader as if they had seen and prayed in front of relics in Jerusalem or Rome: "Here is the place where Our Lord gave the sudar- 
ium [to Veronica]. And Our Lord was very tired and disheveled, spat upon, His holy face covered with blood and sweat; and Veronica went to meet Him, holding her head-shawl, which Our Lord took, and He pressed his holy face against it; and this is the holy sudarium that is shown during the main feast days in St. Peter's church in Rome." ${ }^{33}$

18 As the last example might suggest, the most commonly copied objects of the Middle Ages were probably not shrines or relics but books. ${ }^{34}$ In the early Middle Ages, the principal activity of monastic scriptoria was the replication of texts. ${ }^{35}$ Bede documents this from the beginning of the eighth century, when Abbot Ceolfrith of Wearmouth/Jarrow commissioned three copies of an Italian-made pandect (a Bible bound in one huge volume) known as the Codex Grandior of Cassiodorus. ${ }^{36}$ Along with the replication of texts came the imitation of images that were considered indispensable components of sacred books. Evidence from the same commission by Abbot Ceolfrith supports this assumption. Preserved in Florence is the Codex Amiatinus, one of Ceolfrith's three copies. The Codex Amiatinus includes a full-page miniature of the prophet Ezra that points to an Italian prototype (i.e., the lost Codex Grandior) because of its classical approach to light and space. ${ }^{37}$
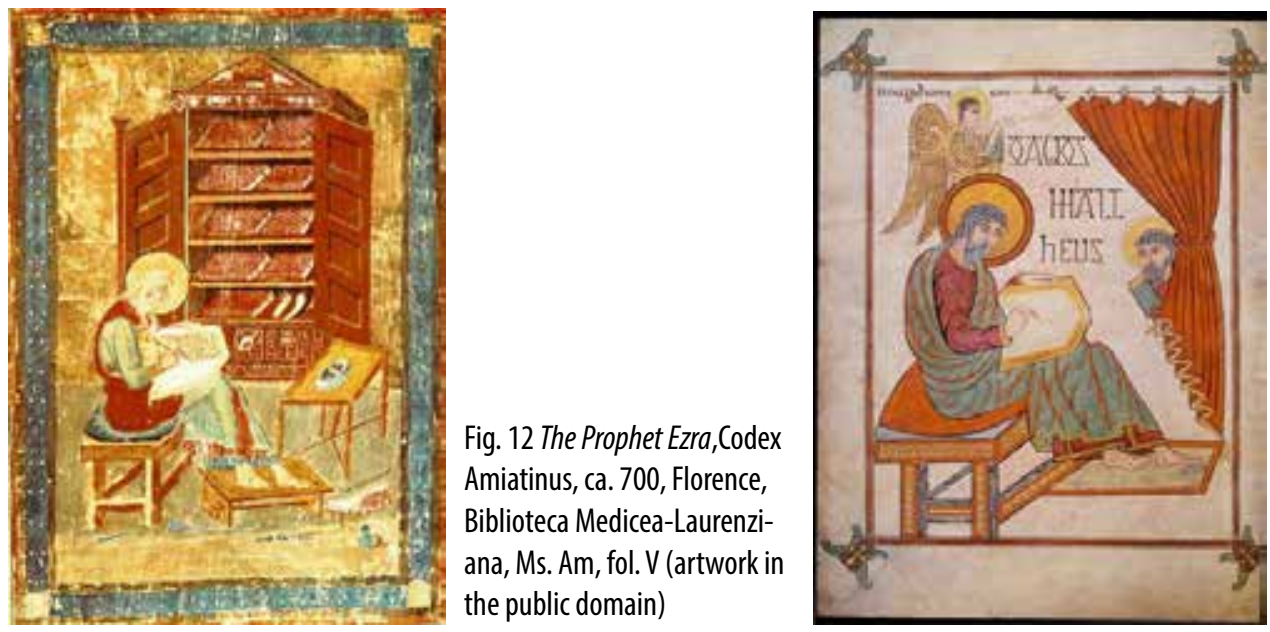

Fig. 13 Saint Matthew the Evangelist, Lindisfarne Gospels, ca. 698, London, British Library, Cotton MS Nero D.iv, fol. 25v (artwork in the public domain)

19 In the master narrative of art history, it is customary to present the Middle Ages as a period opposed to and bracketed between classical antiquity and that era's revival in the Renaissance. ${ }^{38}$ For example, the above-mentioned miniature of Ezra is often compared to the author portrait Saint Matthew the Evangelist from the Lindisfarne Gospels (figs. 12-13). ${ }^{39}$ The point of the comparison is to demonstrate the anticlassical approach of the Hiberno-Saxon artist of the Lindisfarne miniature in comparison to that of the artist of the Amiatinus miniature, who regardless of his own roots tried to imitate a classicizing prototype. With respect to imitation, however, this comparison is partly misleading. Although the comparison certainly points to a shift away from illusionism toward a more symbolic approach to visual forms, this pair of images also testifies to the presumption, shared by the "medieval" and the "classical" artist, that religious images should depend on authoritative models. ${ }^{40}$

20 Consider for example the miniature Saint Veronica from an early prayer book by Glockendon in Munich (fig. 14). This miniature is included as part of the popular devotion to the cult of the Holy Face, that is the image of Christ's face on the sudarium, the veil of Saint Veronica, mentioned 


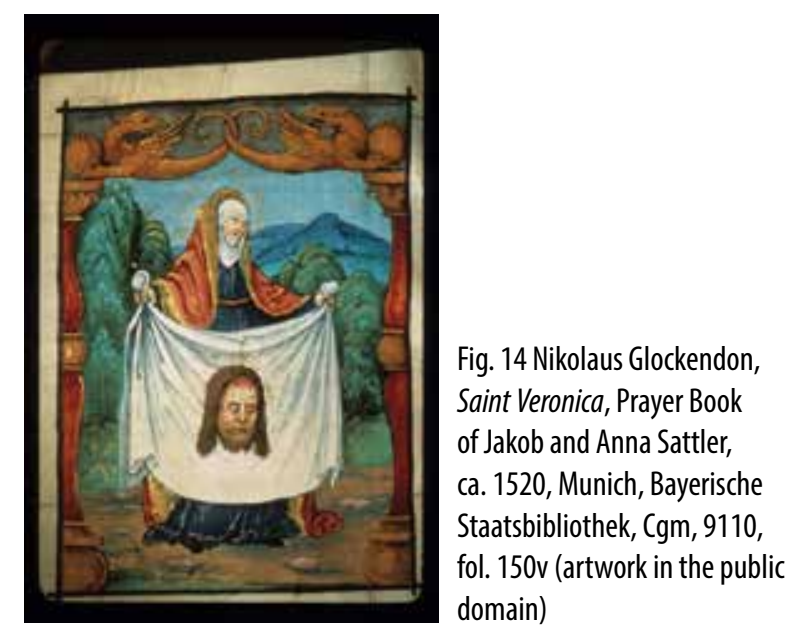

above. ${ }^{41}$ As the rubric before the Glockendon prayer text makes clear, this cult promoted the worship of the image of the Holy Face, not just in its "original" presence, as in the relic of the veil of Saint Veronica, but in any artist's representation of that presence, as in Glockendon's miniature. The rubric offers generous indulgences, or time relieved from purgatory, to the supplicant who venerates the image, including thirty thousand years for the recitation of a single pater noster before it. ${ }^{42}$ One can also earn indulgences for simply looking at the image, or by carrying it on one's person, removed from sight. The rubric makes no distinction between the relic of the Holy Face and the Holy Face in the prayer book. Any version of the Holy Face is the Holy Face.

21 Veronica's veil is an important paradigm for understanding imitation within the medieval tradition. The Holy Face was known in the Middle Ages as the vera icon (true image), because it was produced not by human hands, but by the imprint of Christ's face directly onto Veronica's veil. The text of the prayer to the Holy Face in Glockendon's Munich prayer book begins: "Hail, Holy Face of our Savior, in which there shines the form of godly appearance, impressed on a cloth of snow white, given to Veronica as a sign of love." 43

22 This prayer describes the image as a sign, reflecting the medieval linguistic theory regarding the value of words as surrogates for things. Language, although fallen, was still thought to aspire to the prelapsarian purity of Adam's speech, in which signifier and signified were the same. ${ }^{44}$ When discussing images, Neoplatonic theorists used the term methexis (participation), to describe the positive relationship between a sacred relic and an artist's image of it, inasmuch as any image participates in the "essence" of its model. Early Christian advocates of images used the term overshadowing, taken from Luke 1:35, where the Holy Ghost "overshadows" the Virgin Annunciate, to describe the lasting presence of the model on an image or copy. ${ }^{45}$ Even the pessimistic Origen of Alexandria (185-254 CE) admitted that after the Fall, Adam never entirely lost the image of God (Genesis 1:26) because God's image in the human always remains. ${ }^{46}$ The prayer after Glockendon's miniature directs the reader, "Look at the Face: there is clearly Christ." ${ }^{77}$ The image of the Holy Face attests to the medieval viewer's confidence in the ability of images to transcend the limits of representation. The sacred presence of the sign is transferred from one copy to the next. The Holy Face is a true image, because it is an image in which there is no difference between itself and the thing it represents. 
23 The value of any single exemplar in this tradition, therefore, was as a carrier of the sign (i.e., the face of Christ). This property of an image as carrier allowed replicas of relics or venerated images to function in place of their models, because the image or copy was understood as a means of witness to a sacred presence. Peter Parshall has discussed the term imago contrafacta used in inscriptions by Israhel van Meckenem on two of his engravings from the late fifteenth century. ${ }^{48}$ The term contrafactum has an English cognate, "counterfeit," but Meckenem and other artists used it nonpejoratively to mean a copy that bears witness. Both Meckenem engravings replicate the Imago Pietatis, the mosaic image of Christ as the Man of Sorrows, preserved as a relic of Saint Gregory's Mass at the Church of Santa Croce in Gerusalemme in Rome. ${ }^{49}$ The intent of Meckenem's prints is to offer the viewer-supplicant the same fourteen thousand years of indulgence against purgatory as one would receive for devotions performed before the Imago Pietatis relic in Rome. The Meckenem prints differ in size and decorative detail, but such differences had no impact on the effectiveness of either image, as long as each was identifiable as a copy of the sacred relic.

24 The function of an imago contrafacta as witness actually relaxes the relationship between model and copy and allows room for minor adjustments. Compare, for example, The Man of Sorrows by Glockendon from the Sattler Prayer Book (fig. 15) with its exemplar in an engraving by Dürer (fig. 16) ${ }^{50}$ In both images, Christ as the Man of Sorrows stands before the base of the Cross and displays his wounds. At his feet lie various instruments of the Passion. In Dürer's engraving these include the scourge, the cloak, the dice, and the sponge of vinegar. In Glockendon's miniature, the artist adds to these the spear of Longinus, a whip, nails, and tongs. Glockendon also enhances the image with a background landscape and an elaborate architectural framework.

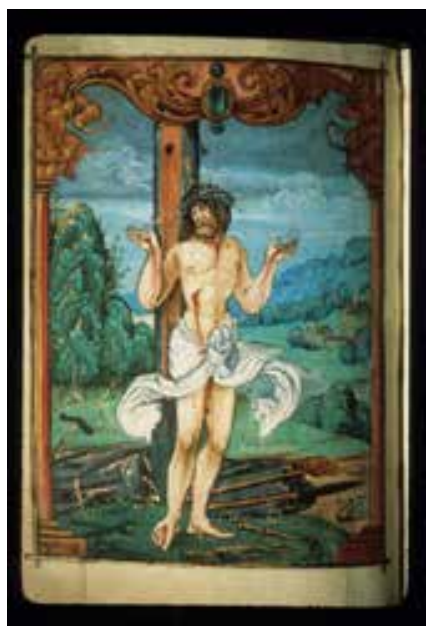

Fig. 15 Nikolaus Glockendon, The Man of Sorrows, Prayer Book of Jakob and Anna Sattler, ca. 1520, Munich, Bayerische Staatsbiblothek, Cgm 9110, fol. 79v (artwork in the public domain)

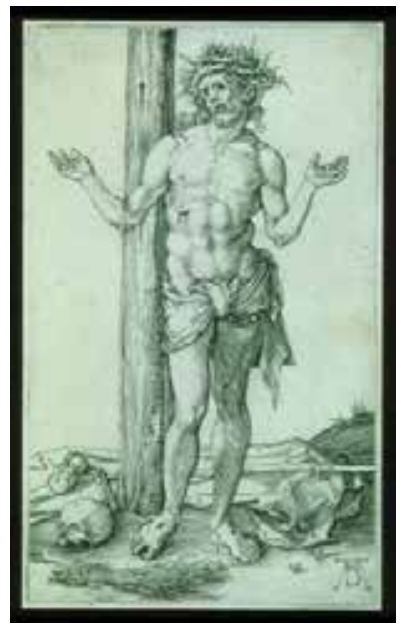

Fig. 16 Albrecht Dürer, The Man of Sorrows with Arms Outstretched, engraving, ca. 1500, Museum of Fine Arts, Boston, Stephen Bullard Memorial Fund (Photo @ 2010 Museum of Fine Arts Boston) (artwork in the public domain)

25 Glockendon's embellishments to Dürer's Man of Sorrows follow a strategy typical of imitation in medieval sacred art. The artist's purpose is not to differentiate his work from another's for the sake of individual style or originality. Nor do Glockendon's additions manifest the late Gothic horror vacui. Glockendon is simply changing his model to suit the function of his image as a devotional aid to a prayer text. The rubric not only explains some of the deviations from the model but also clarifies the specific function of the image in its devotional context:

Whoever while before the picture of the Man [of Sorrows] calls upon the Mercy of 
God, speaks or prays three Our Fathers and as many Ave Maria's, will by decree of Pope Clement receive 34,040 years indulgence. And if the instruments of the Passion of Christ are also depicted, the indulgence is doubled. [Moreover,] each instrument has a special indulgence; accordingly speak the prayer with reverence, and this indulgence is granted by the worthy Father Nikolaus, Abbot of the Monastery of Our Lady in Florence. ${ }^{51}$

26 The purpose of this devotion is to obtain indulgences (Ablass), or time credited against purgatory. ${ }^{52}$ The rubric demonstrates the power of the image as a devotional object, which Glockendon enhances by including the instruments of the Passion, since twice as many years indulgence can be earned if the instruments are included. Each instrument further earns a special, unspecified indulgence, perhaps commonly known to the late medieval supplicant.

27 Once Glockendon's motivations for altering his model become apparent, it is possible to explain some of his other revisions, such as the handling of Christ's loincloth, which billows up around the figure rather than binding it, as in Dürer's version. This alteration appears to indicate Glockendon's preference for late Gothic stylistic conventions. ${ }^{53}$ But it may also serve to fetishize the loincloth as another object on which meditation and prayer for indulgences can be focused. ${ }^{54}$ Glockendon's addition of a suggestively Bavarian landscape serves to emphasize the immediate presence of Christ's sacrificial body in the supplicant's world. The architectonic framework encloses the image in a carved, bejeweled shrinework, as if it were part of a reliquary, and further contributes to the devotional power of the image, which persistently prevails from one "witness" to the next.

\section{Boccaccio's Tale}

28 In the late medieval period, the practice of relying on models while constantly changing them to suit new contexts is characteristic not only of art but also of literature. Gerald R. Bruns associates this practice in literature specifically with the cultural context of the medieval manuscript. Bruns draws "a distinction between two kinds of text: the closed text of a print culture and the open text of a manuscript culture." Bruns explains print culture and its emphasis on authorization: "Print closes off the act of writing and authorizes its results.... There are numerous (numberless) complicated forces of closure in a print culture.... What is printed cannot be altered-except of course, to produce a revised version or edition." 55

29 In the late fifteenth century, one witnesses what Bruns describes as "forces of closure" emerging in the first protective privileges (the forerunners of copyrights). Glockendon's adaptation of prints and paintings by his sixteenth-century contemporaries, however, depended on his participation in an audience that still recognized "the open text of a manuscript culture." Bruns describes this text as one that "opens outwardly rather than inwardly, in the sense that it seems to a later hand to invite or require collaboration, amplification, embellishment, illustration, to disclose the hidden or the as-yet-unthought-of." 56

30 Bruns recalls late medieval examples of such an open text, including those variations of tales passed among writers, including Boccaccio, Chaucer, and Petrarch. Chaucer's Troilus and Crysede is infamous for its "plagiarism" of Boccaccio's Il Filostrato and for its bogus citation to the antique authority Lollius. Yet Bruns understands Chaucer's deception as a narrative strategy in 
which the author "chooses to conceal his originality," preferring to speak "with a fictional authority that has been carefully constructed." ${ }^{77}$ Chaucer's motivations for the retelling of Boccaccio's tale included the translation from one vernacular language into another. Bruns explains the medieval concept of translatio(literally, turning), as it relates to the concept of the open manuscript text:

...in a manuscript culture to translate means also the turning of a prior text into something more completely itself, or something more than what it literally is. I can refine this somewhat by saying that in a manuscript culture the text is not always reducible to the letter; that is, a text always contains more than what it says, or what its letters contain, which is why we are privileged to read between the lines, and not to read between them only but to write between them as well, because the text is simply not complete-not fully what it could be, as in the case of the dark story that requires an illuminating retelling. ${ }^{58}$

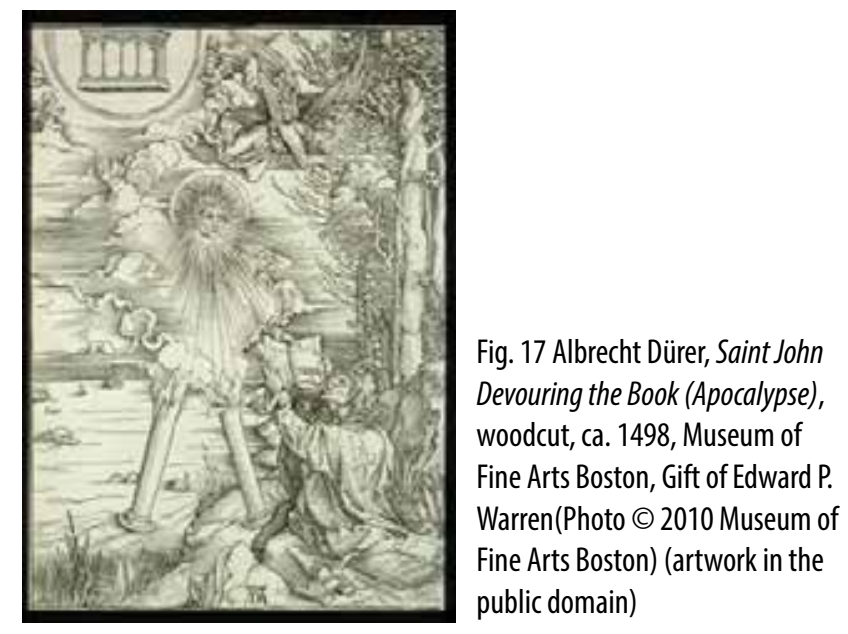

31 In a woodcut from Dürer's illustrated Apocalypse one discovers medieval translatio in literal terms (fig. 17). John, author of the Revelation, is commanded by a fearsome angel to eat a book. Although the subject results in a rather astonishing visual image, the angel's point is that John must first digest one sacred text in order to write another. Glockendon digested the prints of Dürer and other artists, turning each black-and-white composition into "something more completely itself, or something more than what it literally is." To Glockendon and his patrons, an image in print offered a "dark story that requires an illuminating retelling." Glockendon's art can be compared to what Bruns describes as "the grammarian's art of embellishment, "which "adds lustre" and "illuminates what is hidden in the original," which "is, in any case, tacitly unfinished."

32 The concept of finishing is important to understanding imitation in the art of manuscript illumination. The common division of labor in a scriptorium or an illuminator's shop usually produced a single work of art as a collaborative project. The painted decoration of a manuscript came late in the bookmaking process, after the cutting, ruling, and layout of the pages. The program of illustration could be arranged only after the scribe's organization of the text. ${ }^{60}$ Decorated initials could be added only after the layout of the text was certain to the letter, and sometimes not until the script was completely in place. The manuscript wasn't finished until the work of the illuminators was done. 
33 As Douglas Farquhar points out, the illuminators' traditional practice of working from model books contributed to repetition in illumination. ${ }^{61}$ Working from existing patterns also places the illuminator in the position of finisher. In Glockendon's work, however, the model book was largely replaced by contemporary prints. Glockendon's painted versions of printed images reflect a contemporary taste for hand-colored prints, works often misunderstood by modern historians. Although reviled by Erasmus, the application of pigments to prints was a common sixteenth-century practice, as demonstrated by a 2002 exhibition at the Baltimore Museum of Art. In the catalog to the exhibition, Susan Dackerman challenges modern notions of originality that have denigrated the work of Briefmaler (print-colorists). ${ }^{62}$ Briefmaler such as the Mack family of Nuremberg added colors to prints, in the same tradition as German artists who added gold and pigments to sculpted altarpieces. Tilman Riemenschneider's now dispersed altarpiece from Münnerstadt was painted and gilded by Veit Stoss some ten years after its completion. Consistent with his contemporaries' indifference to originality, Riemenschneider was paid 145 gulden to design and carve the altarpiece, but Stoss received 220 gulden to paint it. ${ }^{63}$ The record of payments on the altarpiece from Münnerstadt not only demonstrates how collaboration flourished in this period but also emphasizes how the process of translatio could increase the value of a work.

34 Bruns cites another example of literary translatio in Petrarch's Latin version of the "Tale of Griselda," which Petrarch, like Chaucer, borrowed from Boccaccio's Decameron. ${ }^{64}$ Petrarch's work compares with Stoss's gilding of Riemenschneider's altarpiece, or with Glockendon's embellishing the compositions of Dürer and other printmakers, because it involves "finishing" a work of lower value (an entertaining story in the vernacular), in order to turn it into a work of elevated style (a moralizing treatise in Latin): "Petrarch translates Boccaccio's story not only laterally into a different tongue but upwardly into a more noble style (stilo nunc alto), and this noble style stipulates in turn large amplification of matter....Petrarch transposes the story from the locality of the vernacular to the universality of Latin, which is a way of finishing the story...a way of enshrining the story." 65

35 Several authors translated Boccaccio's tales into German. Heinrich Steinhöwel (ca. 1411-1479) produced Griseldis, first printed by Günther Zainer of Augsburg, to appeal to a popular audience. It became a best-seller, with nine fifteenth-century printings and at least eleven more in the sixteenth century. ${ }^{66}$ Niklas von Wyle (ca. 1415-1479), inspired by his friendship with the humanist Enea Silvio (Pope Pius II, r. 1458-64), produced a miscellany of works called Translatzen, first printed by Konrad Fyner at Esslingen in 1478. ${ }^{67}$ A former Nuremberg Stadtschreiber (city secretary), who also held the position of boarding-school teacher at Esslingen, Wyle translated this collection of "lustig und kurtzwilig" (amusing and entertaining) tales and short treatises from Latin into German, including one tale originally from theDecameron, "Guiscard und Sigismunda." In a forward to this tale Wyle associates his work with Petrarch's translation of "Griselda." ${ }^{68}$ As part of a career ambition to develop Kunstprosa (an artful, if not artificial, literary style of writing), Wyle intended to refine written German through the adaptation of humanist themes, classical rhetoric, and Latin syntax. Although Wyle translated from Latin into a vernacular language, he saw translatio as an elevating process that resulted in "guot zierlich tütsche...und nit wol verbessert werden möchte" (good, elegant German that could not be improved upon). ${ }^{69}$

36 As a panel painter and internationally renowned artist, Dürer may have been considered by his 
peers to be Glockendon's professional superior. But manuscript illumination was clearly a more expensive, and arguably a more "zierlich" medium of text illustration than that of prints. Part of Glockendon's imitative task as an illuminator was to elevate the prints of Dürer and others into the stilo nunc alto, or "heigh stile," of illuminated manuscripts. I have mentioned previously how Glockendon's buoyant handling of colors served to transform Dürer's Resurrection into a work of celebration. Glockendon's sumptuous pigments highlighted with gold also served to elevate Dürer's woodcut in terms of style. This stylistic ennoblement, moreover, was a basic assumption of his imitative enterprise. For Glockendon and his audience, artistic imitation was not associated with degraded results. On the contrary, an imitative work of the late medieval tradition could be considered continuous with or even elevated from its model or source.

\section{Gutenberg's Commerce}

37 Between the years 1450 and 1454 Johannes Gutenberg of Mainz printed from movable type about 180 copies of the double-column, 42-line Bible that created a revolution in bookmaking and related artistic media. ${ }^{70}$ It was no accident that Gutenberg chose the Bible as the text to announce his invention in the marketplace. To produce a complete Bible in multiple copies was a radical advertisement of what his new process could accomplish. ${ }^{71}$ Before the invention of printing, the text of the Bible was often codified as constituent parts, such as the Psalter, the Gospels, the Revelation (Apocalypse), or produced in paraphrased versions, such as the Bible Moralisée. Gutenberg's invention, however, put printers in a position to respond, perhaps even to help generate, the growing demand for the unabridged Bible. The advantage of printing in this context left many illuminators to rely on printers for work. ${ }^{72}$

38 It is important to recognize that the work of printers and printmakers in this period significantly influenced the work of illuminators. Few scholars have studied the impact of printing on book illumination in post-Gutenberg Germany. Eberhard König, however, has demonstrated that the change in conditions in book production in this period pressured illuminators to accommodate standardization and replication in their work. ${ }^{73}$ Although illuminators were often called upon to decorate early printed books, the production methods of Gutenberg set a precedent that precluded extensive programs of painted illustration. Some preserved copies of the 42-line Bible have illuminated initials and borders, but "following its example, not a single incunable printed in Germany provided space for miniatures." ${ }^{74}$ While printing methods restricted programs of illustration, the work that was available for illuminators compelled them to keep pace with new schedules of production that discouraged customization. Even beyond practical circumstances, printing reinforced an aesthetic that rejected pictorial innovation. König cites the example of a talented but anonymous illluminator who worked at Mainz for Johannes Fust, Gutenberg's business partner. This anonymous artist added illuminated decoration to several printed books, including two copies of the 42-line Bible preserved at Burgos and New York, respectively. According to König, this illuminator was obviously accomplished but for the sake of standardization and consistency suppressed his individuality as an artist, "even if he had to give up what we might regard as his real quality." 75

39 In fifteenth-century Holland single-leaf prints produced a measurable impact on the market circumstances for book illustration. James Marrow discusses three different artistic strategies that Dutch illuminators experimented with to gain competitive advantage over printmakers. ${ }^{76}$ The 
first of these was to produce single-leaf miniatures that they sold as independent images to be inserted into books at their owner's discretion. This strategy freed the illuminators from the burden of commissions for complete manuscripts and enabled them to compete with contemporary printers who sold woodcuts and engravings as independent, self-contained images. The second strategy the Dutch illuminators used was to change their painting technique from polychrome to grisaille. A picture in grisaille looked more like a printed picture and was cheaper to produce in terms of both materials and labor. The third strategy used by the Dutch illuminators was replication. They used replication in different ways. For example, some created assembly-line systems of production that included tracing, so that one shop could produce multiple copies of the same image in the manner of the printmakers. Others copied the work of printers-not only prints but also printed books. The Harley Hours in the British Library (Ms. 1662), for example, may be a manuscript copy of a printed book illustrated by the so-called Master of the Berlin Passion. ${ }^{77}$ There are in fact many manuscripts from the fifteenth through the sixteenth century that are copies of printed books, and many examples of hybrid works that demonstrate the entrepreneurial spirit of the artists who worked in book illustration during this period. ${ }^{78}$

Georg Glockendon the Elder, Nikolaus's father, was just this sort of entrepreneurial artist. According to Neudörfer, Georg illuminated choir books, missals, and Wappenbriefe (official charters authorizing coats of arms). He also ran a large business in gemalte Briefe (hand-painted documents and prints). ${ }^{79}$ Works preserved by Georg include not only (attributed) illuminated manuscripts but also several cartographic projects in which he collaborated with Erhard Etzlaub: a hand-painted pre-Columbian globe of the world, a 1492 printed map of Franconia, and a printed (some issues hand-colored) map of central European routes to Rome for the Jubilee year $1500 .{ }^{80}$ Georg also published a printed almanac, a 1509 printed translation of Jean Pèlerin's book on the art of perspective (translated by Georg's son Johann), and various printed and hand-colored broadsheets. Neudörfer mentions that Georg's sons and daughters all helped out in his busy workshop, and that his sons Nikolaus and Albrecht became "berühmte Illuministen" (famous illuminators). ${ }^{81}$

41 There was at this time a great deal of artistic innovation going on, but it was innovation based on competition and artistic exchange, not on artistic individuality: "The pace of artistic interchange quickened considerably in Northern Europe during the fifteenth and sixteenth centuries, in parallel with changes in its nature....For just as the appearance of the printed word led to an intensified and broadened commerce in ideas, so the development of printed images, both in woodcuts and engravings, led to an expanded commerce in visual ideas." 82

42 The commerce in visual ideas discussed above by Marrow, included not only patterns and compositions but also new methods of production, and "a new attitude toward the use and reuse of images...with all that phrase implies about the easy dissemination and replication of artistic ideas." ${ }^{83}$ Illuminators were enthusiastic participants in this commerce, for the advent of printing forced them to face the unprecedented challenge of a new method of book illustration and a new kind of book. This new book rapidly asserted itself in the marketplace, where it sold at high volume for a low price. ${ }^{84}$ An eventual response from sixteenth-century illuminators would be to change their market strategy and present their product as a high quality alternative to the printed text. But illuminators were trained in a tradition that presumed replication, so they also sought to compete with printers in the wider market for illustrated books and documents, which until the 
invention of printing had exclusively belonged to them.

43 Against this background we can begin to measure Nikolaus Glockendon's own survival skills in the tightening market for book illumination. Although he did not publish printed materials like his father and brother, or use grisaille technique like the Dutch illuminators, he did produce single-leaf miniatures, many of which appear in manuscripts made for Cardinal Albrecht of Brandenburg. Cardinal Albrecht not only commissioned and collected complete manuscripts but also purchased dozens of single-leaf miniatures by Glockendon, Simon Bening, and Sebald Beham. ${ }^{85}$ These miniatures were inserted into books made for the cardinal at his Halle scriptorium, headed by George Stierlyn, a scribe who painted initials and borders but not miniatures. Stierlyn's manuscripts, such as a Book of Hours (Ms. 9) at Aschaffenburg, comprise outsourced projects with illustrations by artists who possibly never even met each other (fig. 18) ${ }^{86}$ Not surprisingly, the single-leaf miniatures produced for such manuscripts often consist of compositions based on prints. The demand for single-leaf miniatures in the sixteenth century represents evidence that illuminated manuscripts made after the invention of printing competed with printed books. Manuscripts retained a special attraction for wealthy patrons as luxurious, but not necessarily unique, objects. Cardinal Albrecht's manuscripts were not only expensive and prestigious objects of ownership but also repetitions of works of art and texts that he already owned in print. Book illuminators retained a market share after the advent of printing, not because of their product's singularity but rather because of their ability to compete in the new economy created by Gutenberg. ${ }^{87}$

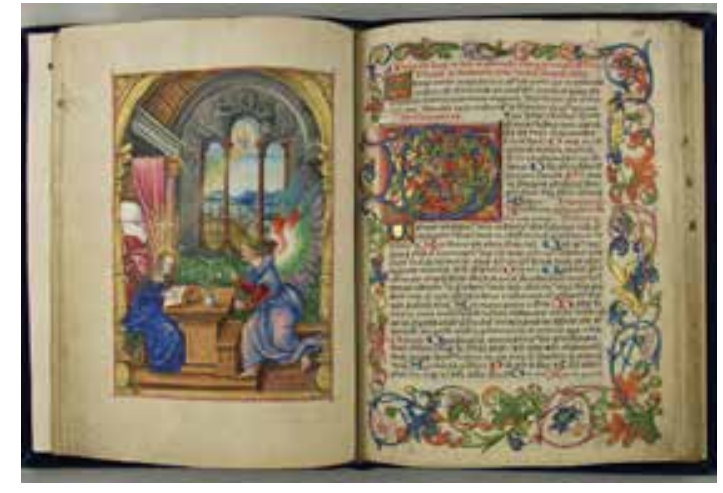

Fig. 18 Georg Stierlyn and Nikolaus Glockendon, Hours of the Virgin, Aschaffenburg, Hofbibliothek, Ms. 9, fols. 15v-16 (artwork in the public domain)

\section{Panofsky's Project}

44 In order to completely come to terms with the context in which Nikolaus Glockendon thrived as an imitator, one must address the issue of individuality and self-consciousness associated with Renaissance art in general and with Albrecht Dürer in particular. Erwin Panofsky, for example, explained that Dürer preferred producing prints to paintings because, "the graphic media were the most appropriate means of expression for a mind dominated by the idea of 'originality"'" 8 To be sure, Dürer developed an assertive sense of artistic territory, as he actively sought to protect much of his printed work from fraudulent replication. But we should also recognize that Panofsky, whose study of Dürer still dominates the scholarship of this period, saw it as his mission to elevate the history of art in Renaissance Germany to a level of scholarly recognition comparable to that of Renaissance Italy. 
tions" in Panofsky's "medium-bound" art history that depends on a hierarchy of media, single authorship, and view of the artist as a unique creative force: "Modern notions of originality therefore cast the work of the (often unknown) colorist as an adulteration of the printmaker's work. The same conception of originality, however, was not at play during the Renaissance, when workshop practices dominated the production of printed images." 89

Modern scholarship often overlooks the fact that many of Dürer's prints were created neither as single-leaf prints nor as compendia of images but as components of workshop-produced illustrated books. Recently, however, a 2008 exhibition at Nuremberg highlighted Dürer's work as a publisher and book illustrator. ${ }^{90}$ The exhibition included the three large-format volumes that the artist referred to as "die drei grossen Bücher" (the three large books): the so-called Life of the Virgin, Apocalypse, and Large Passion. ${ }^{11}$ Also included in this exhibition were Dürer's instructional books for artists, two copies of the so-called Small Passion, title pages, ex libris plates, and various marginalia. Dürer also contributed to the marginal decoration of a printed prayer book for Emperor Maximilian I (not included in the exhibition) and had plans to publish an illustrated prayer book known as the Salus Animae, which, however were never fulfilled. ${ }^{92}$

Dürer published the first of his books, the Apocalypse, in 1498, with a Bible text set in type borrowed from his godfather Anton Koberger. ${ }^{93}$ Panofsky, in seeking to emphasize the dominating presence of Dürer's illustrations, describes their relationship to the text as such: "Dürer...wanted...a continuous yet brief series of pictures neither interrupted by the text, nor inserted in the text, nor, of course, interspersed with the text. He therefore reserved the front of his huge pages for woodcuts free from inscription and printed the text on the back." ${ }^{94}$

Wishing to free Dürer's prints from their role as illustration to a text, Panofsky elevates them to a level of autonomy traditionally reserved for panel painting. In the effort to further his agenda, however, he misrepresents Dürer's work, suggesting that the artist had asserted his sense of self-expression over scripture itself. Panofsky gives us the impression that the illustrations to the Apocalypse were actually single-leaf prints with complementary text printed on the verso. The text on the back of each illustration of the Apocalypse, however, corresponds with the image on the following folio, not the image on the recto side of the same folio as Panofsky implies. The relationship between text and image only works if the folios are bound together in a codex format. The text even includes a rubric for the illustration on the following page, such as "sequitur tercia figura" (here follows the third figure) The pictures are indeed "interspersed" with the text. This format applies to all the "drei grossen Bücher" as well as to the Small Passion.

By 1511 Dürer had printed editions of the Apocalypse, the Large Passion, the Life of the Virgin, and the Small Passion with an imperial privilege of protection against unauthorized copies. Although an early forerunner of artistic copyright, Dürer's privilege should not be understood in modern terms. I translate Dürer's privilege from the Latin as follows:

Hey, you perfidious thief of other's work and talent! Beware not to lay a reckless hand on this our work. Then know, by the glorious Emperor of the Romans, Maximilian, are we entitled, that no one may dare 
reprint these pictures with counterfeit blocks, or sell them already printed, within the borders of the Empire.

But if you, out of contempt or criminal greed act to the contrary, know surely that you must submit to the confiscation of your property and great penalty. ${ }^{95}$

In his book on Albrecht Dürer, Joseph Koerner interprets Dürer's privilege as "a warning to all copyists," who might steal Dürer's "unique pictorial invention." Koerner builds on Panofsky's project in order to invest Dürer with an essentially modern self-consciousness. ${ }^{96}$ Koerner's views on originality are informed by those of Harold Bloom, whose literary theory presupposes the anxiety of an epigone burdened by the accomplishments of an established master. ${ }^{97}$ Considering, however, the language of the privilege and the evidence regarding Nikolaus Glockendon and his artistic and professional relationship to Dürer, we may question whether such a modern sense of originality is represented in Dürer's privilege. If Koerner is correct, Dürer should have regarded Glockendon as a competitor and thief of his work (labor) and talent (ingenium).$^{98}$ But we know instead that Glockendon worked with Dürer's approval, as attested to by the previously discussed documentation concerning the Missale Hallense. The letter from Dürer to Cardinal Albrecht and extant preliminary drawing by Dürer make clear Dürer's supportive position, even though the manuscript referred to is filled with copies of Dürer's imperially protected prints. We also know that Glockendon copied Dürer's compositions in other manuscripts, including the prayer books in Modena (fig. 10) and Munich (figs. 14-15) previously discussed.

51 In spite of the privilege's claim to protect the artist's labor and talent, Dürer did not object to Glockendon or any other artist copying free-hand from his prints. What he did object to were forgeries, pictures printed suppositiis formis, i.e., on "counterfeit blocks."99 My translation of suppositiis formis, departs from Koerner's "spurious forms," and I believe the difference between these translations is significant. "Forms" in the artistic vocabulary of sixteenth-century Nuremberg were not compositional forms but negative forms, such as the molds used for bronze casting or the woodblocks used for printing. ${ }^{100}$ A Formschneider was a craftsman who cut woodblocks, not an artist who carved designs. The technique for carving a woodblock for printing or a wooden model for casting was the same: the artist cut away the negative space from the form. Artists such as Peter Flötner made both woodcuts and plaquettes cast in metal from wooden forms. ${ }^{101}$

52 Dürer developed a new sense of proprietary rights about his work, not because he had developed a modern sense of artistic originality but rather because he literally owned the blocks or plates from which new copies could be made. Before the invention of printing, a medieval artist did not acknowledge any ownership of his work because he retained no physical ownership of it. Dürer was protecting something made in his shop that belonged to him, and he could prove it. Dürer's privilege warns that the punitive measures to be taken against counterfeiters include the confiscation of property, literally, "the goods" (bonorum), i.e., the forged works of art. The focus is on the process and product of making, not on the ideas or intellect behind it. The property under protection is material, and its violation as artistic territory is to be paid for in kind. This sense of artistic property was also demonstrated in the litigation of 1519-20 between Gerard David and his assistant Ambrosius Benson. The dispute involved two trunks belonging to Benson, the contents of which included patterns that David alleged belonged to him. The patterns at issue, however, were 
physical property, not intangible designs. ${ }^{102}$ The famous case against Christian Egenolff for copying botanical illustration was brought in 1533 by the publisher Johann Schott, who owned the woodblocks and had received an imperial privilege that protected his ownership. Hans Weiditz, the artist who designed the illustration, was not involved in the case because he had no ownership at stake. ${ }^{103}$

53 Dürer's notion of artistic property can be measured against the status of the designing artist in a collaborative work known as the Silver Altarpiece of King Sigismund I of Poland, made for the cathedral of Cracow in the years 1531-38. ${ }^{104}$ Hans Dürer, Albrecht's brother, created the designs for this work, while Georg Pencz executed the paintings on the exterior of the wings. Georg Herten did the wood carving, and the sculptor Peter Flötner prepared the wooden models and figures for the brass casts, which were made by Pankranz Labenwolf. The silver reliefs were produced by the goldsmith Melchoir Baier. The price of the finished altarpiece came to the exorbitant sum of 5,801 gulden, 8 groschen. ${ }^{105}$ The painter Georg Pencz received 290 gulden for his work, and the wood-carver Georg Herten received 30 gulden. Hans Dürer was paid 12 gulden for his designs.

54 One could interpret these terms of compensation as an indication of the inferior talents of Dürer's brother. Hans Dürer, however, held a prestigious position as court painter to King Sigismund at the time. As court painter Hans Dürer may have received a regular salary, but the unimpressive fee for his contribution to a work of such great value reflects a general view regarding artists' designs in sixteenth-century Germany. The relative devaluation of Hans Dürer's work, moreover, is related to the limits of ownership that an artist assumed concerning his work in this period. The language that declares his brother Albrecht's privilege as based on labor and ingenium is inflected with both a sense of hard-toiled craftsmanship and of gifted intellect. The word labor in this context represented an alternative to ars (skill) or manus(hand), all of which index the labor and physical aspect of artistic production. ${ }^{106}$ Even as Albrecht Dürer aspired to the humanist values associated with ingenium, the rights of the deserving artisan motivated his privilege and prevailed among sixteenth-century German artists, including those who collaborated on the Silver Altarpiece.

55 Further evidence of the notion of artistic property in this period can be discerned from an incident preserved in Vasari's Lives. Vasari records that in 1506 (before the date of the privilege) Dürer brought a lawsuit against Marcantonio Raimondi for publishing engraved copies of woodcuts from the Life of the Virgin. ${ }^{107}$ The agreement reached by the Venetian court was that Marcantonio could still issue copies of Dürer's prints, but not with Dürer's monogram. Koerner feels that the function of Dürer's monogram, or Handzeichnung, "would have been precisely to claim authorship for the composition." ${ }^{108}$ I would, however, reconsider this assumption. The monogram protects property, but that property may be more material and technical than intellectual. Rather than assume that Dürer wanted to stop Raimondi's copies altogether, we should consider that he may have received exactly the judgment he wanted, which was to stop works made suppositiis formis that buyers might confuse with those made by his own hand or in his own shop. Raimondi himself may have been happy to receive a ruling about the matter, as there are engravings by him with both Dürer's and his own monogram, as if he wasn't really sure how to identify copies of signed prints. ${ }^{109}$ In her discussion of Marcantonio's copies after Dürer, Lisa Pon suggests that the 
Italian engraver's use of Dürer's monogram “was not so much a plagiarist's blunder, but...a publisher's acknowledgement of a model that was in any case not protected against copying in Venice." ${ }^{110}$ Although Pon characterizes Dürer as "a possessive artist-author," she also recognizes that Dürer's monogram and privilege may have functioned separately, as the privilege was "granted more on the grounds of his function as the publisher of the book, rather than as the creator of the images." 11 Recall that Albrecht Glockendon, Nikolaus's brother, served as publisher for the prints of other artists, including Sebald Beham and Erhard Schon, and advertised a privilege that protected his rights, not theirs. ${ }^{112}$ Because privileges granted during this period sometimes protected vendors who had little or no part in the creation of the products they offered for sale, the use of the modern term Urheberrecht (copyright, literally creator-right) in this context seems especially anachronistic. ${ }^{113}$

In her study of Italian printmakers, Evelyn Lincoln finds that even in Italy concepts of authorship and ownership during this period were at best elastic: "It is obvious, in the vocabulary of the print personnel and in the subject matter of the prints, that originality was not located in a notion of absolute novelty as to subject matter or even medium; neither was authorship fixed in any single image or claimable by a single person." 114 Vasari himself held no disdain for imitators.

His Lives includes a flattering biography of Giulio Clovio, the illuminator who copied works by Michelangelo and other artists (including Dürer) to create dynamic miniatures and elaborate border decorations in a thoroughly Italianate style. Vasari describes in great detail the Book of Hours Giulio completed for Cardinal Alessandro Farnese in 1546 and even celebrates the illuminator's imitative gifts: “...Don Giulio has surpassed in this field both ancients and moderns and... has been in our times a new, if smaller, Michelangelo." 115 Some of the miniatures Guilio created are indeed smaller Michelanglos. Others are illuminated versions of Dürer prints, comparable to miniatures by Nikolaus Glockendon (figs. 19-21).

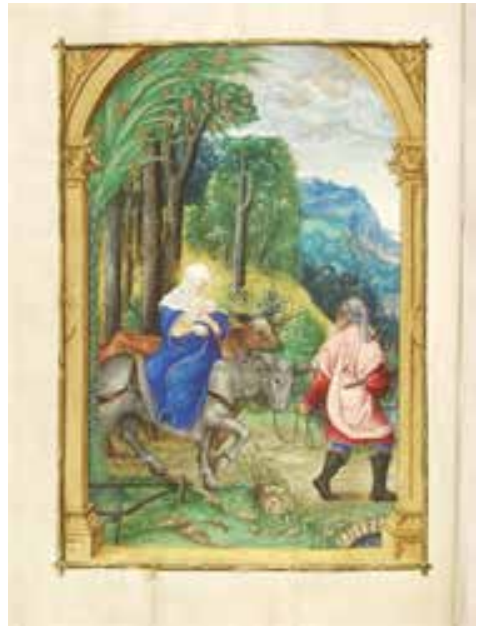

Fig. 19 Albrecht Dürer, The Flight into Egypt (Life of the Virgin), woodcut, ca. 1504, Museum of Fine Arts, Boston, Centennial Gift of Landon T. Clay (Photo @ 2010 Museum of Fine Arts Boston)(artwork in the public domain)

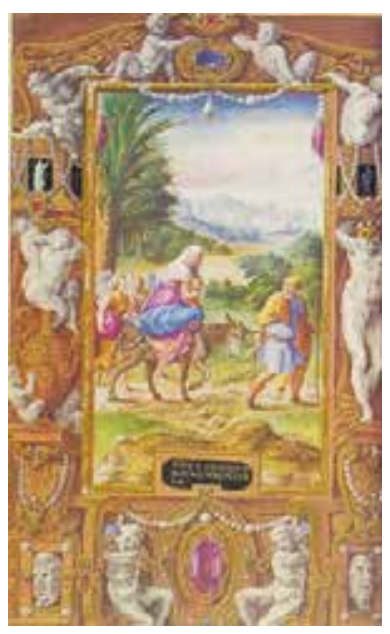

Fig. 20 Giulio Clovio, The Flight into Egypt, Farnese Hours, New York, Morgan Library, M.69, fol. 42v (artwork in the public domain)

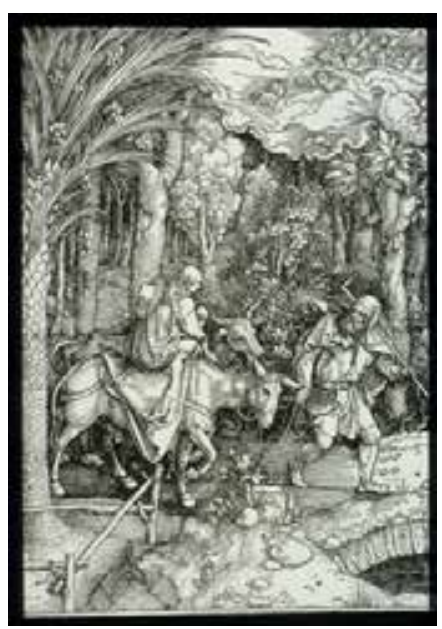

Fig. 21 Nikolaus Glockendon, The Flight into Egypt, Hours of the Virgin, Aschaffenburg, Hofbibliothek, Ms. 9, fol. $32 v$ (artwork in the public domain) 


\section{Neudörfer's Snail}

58 According to Gerald Strauss, the use of punch marks or stamps as a code of authenticity was regulated in Nuremberg manufacturing. ${ }^{116}$ In the late fifteenth century, for example, the city produced regulations regarding marks identifying armor, and in 1498 stipulated that the official Beschau (viewing mark) was to be the half-eagle arms of the city. ${ }^{117}$ Although extant works from before the mid-sixteenth century indicate that master's marks were not consistently applied, Nuremberg goldsmiths also used various punch marks to identify themselves and/or their city. Nikolaus Glockendon's frequent use of a reverse $N$ in his signature $(N G)$ plays off the recognition of the reverse $N$ as a mark of Nuremberg craftsmanship. ${ }^{118}$ The artist's substitution of the cipher of his town for the cipher of his name not only associates his work with that of the trades but also reveals the corporate and commercial inflection of a signature that a modernist might read solely as an index to a personality. Many miniatures by Glockendon are not signed, moreover, and it is not at all clear that his or even Dürer's signature should be interpreted in the same manner as that of a modern artist. Nuremberg painters, illuminators, and printmakers were members of the unregulated "free" crafts (freien Kunste) and did not enjoy the same legal status as those belonging to the "sworn" or regulated crafts (geschworne Handewerke). ${ }^{119}$ Beginning in 1477 and throughout the sixteenth century Nuremberg painters, illuminators, and Briefmalerrepeatedly petitioned the city council for regulated status. ${ }^{120}$ Dürer's insistence that his monogram be protected should be understood in this context: a claim to be deserving of the same respect as a master of any sworn trade. ${ }^{121}$

A treatise written at Nuremberg in 1547 associates art with the journeymen trades. The author, Johann Neudörfer, represents the culturally blurred distinctions between art and craft in his Nachrichten von Künstlern und Werkleuten. ${ }^{122}$ Neudörfer's Nachrichten consists of a collection of short biographies of about eighty Nuremberg artists and artisans who worked during the sixteenth century. It includes essays about stonemasons, wood-carvers, bronze-casters, goldsmiths, bell-makers, fountain-makers, painters, wood-block cutters, scribes, illuminators, coats of arms-makers, stained-glass painters, cabinetmakers, organ builders, lute-makers, book printers, and papermakers, as well as locksmiths, clock-makers, cobblers, embroiderers, furriers, carpenters, plumbers, screw-makers, gear-makers, eyeglass-makers, wagon-makers, scales-makers, and coin-makers. Neudörfer's discussion of these producers reveals specific values regarding artistic labor and talent.

60 Neudörfer's subjects include Nikolaus Glockendon and Albrecht Dürer, as well as Nuremberg artists such as Veit Stoss, Hans von Kulmbach, and Georg Pencz. With carpenters and clock-makers they appear to have one thing in common: they are all craftsmen, skilled individuals who work with their hands. Neudörfer, himself a master calligrapher who collaborated with several of the artists he writes about, reveals his appreciation for the work of the hand in several individual biographies. ${ }^{123}$ He exclaims, for example, that the stonemason and sculptor Adam Kraft was ambidextrous: "Er war mit der linken Hand zu arbeiten gleich so fertig als mit der rechten..."124 One sculptor, named Simon with the Lame Hand, is praised for his work as sculptor, goldsmith, and clock-maker, and maker of all sorts of other "künstlichen Ding," (skillfully-crafted things) in spite of a crippled hand. ${ }^{125}$ To emphasize the manual skills of the wood sculptor Peter Flötner, Neudörfer notes Flötner's ability to carve intricate figures on small natural objects: a cow horn with 113 different faces of men and women and a piece of coral with little animals and mussels, so 
that they appeared to grow on it. ${ }^{126}$

61 Along with the skilled hand, Neudörfer valued a craftsman's ability to transform materials. In his account of the eyeglass-maker Hanns Ehemann, Neudörfer relates a story of how this craftsman once took a Venetian drinking glass, threw it on the floor, burned the pieces, stretched them in the fire into a sheet thin as paper, and turned them into a pair of crystal eyeglasses. ${ }^{127}$ With filial pride he presents an account about his father, Stephan Neudörfer, a furrier who once received a job from a rich Venetian merchant requiring him to soften a sable pelt, in order that the man's wife could wear it around her neck. The elder Neudörfer treated the pelt and achieved such remarkable results that the merchant was able to pass the pelt through his seal ring. ${ }^{128}$ Neudörfer also praises the ability of Hieronymus Gärtner, known for his work in architecture and water engineering, to carve tiny pieces of wood into lifelike objects, such as a cherry supporting a mosquito with wings so delicate they would move if someone blew on them. ${ }^{129} \mathrm{He}$ gives similar credit to Wenzel and Albrecht Jamnitzer, goldsmiths who once presented him with a silver snail, cast with tiny flowers and plants that would also respond to a breath of air. ${ }^{130}$ The Jamnitzer brothers were renowned for this sort of work, in which they cast small animals and plants directly from real specimens. The life-casting process involved extraordinary skill with materials, but no drawing or design, and was praised not only by Neudörfer but also by Vasari in the preface to his Lives. ${ }^{131}$ These authors, craftsmen in their own right, did not view life casting as some form of cheating the artistic process. For them life casts "demonstrated the powers both of nature and its transformation by human artifice." 132 A literal copy of a specimen from nature was valued just as was a well-executed copy of another's artist's work.

\section{Glockendon's Art}

62 The purpose of this essay has been to develop a culturally and historically sensitive consideration of the art of Nikolaus Glockendon of Nuremberg. I have presented Glockendon as an artist of high technical achievement, including his masterpiece of manuscript illumination, the Missale Hallense of Albrecht of Brandenburg. But because of Glockendon's reliance on the compositions of Dürer and other artists, I have also considered a series of issues in order to conceptually frame the role of imitation in Glockendon's work. I have presented this work as a continuation of medieval tradition, exemplified not only in the regenerative nature of sacred imagery but also in the transmission, re-creation, and reinterpretation of borrowed works in secular literature. Turning to the historical circumstances of the fifteenth century, I described the impact of the invention of printing on illumination, in so far as it compelled illuminators to participate in the commerce of book production with its new demands for replication and standardization. Focusing on Glockendon's more immediate context, I examined Glockendon's professional relationship to Dürer in order to challenge a notion of artistic originality central to Panofsky and Koerner's presentation of the Nuremberg printmaker as the epitome of Renaissance genius. Consequently I evaluated the terms of artistic property presented in Dürer's imperial privilege and compared these with projects by contemporary artists to reveal a notion of artistic property more tangible than intellectual, with little regard for "original" designs. I then measured contemporary standards of artistic value in the essays of Johann Neudörfer, who associated art with the journeyman trades and prized the skill of the hand and the manipulation of materials, even in the absence of drawing and design. 
understanding of German Renaissance art necessitates the discovery of values particular to a culture different from our own. The subjective application of modern (and modernist) notions of originality to the art of other periods and cultures, needs to be replaced by the adjustment of our responses to the reception of images appropriate to an artist's own time and place.

\section{Acknowledgements}

I wish to thank Alison G. Stewart, Jeffrey Chipps Smith, and Larry Silver for reading earlier versions of this article and providing inspiring critical commentary. I am also grateful to James Marrow for enthusiastically introducing me to the art of Nikolaus Glockendon, to Robert Suckale and Franz Machilek for generous guidance when I first began my research in Germany, to Jean Givens and Elaine Tennant for thoughtful and challenging responses to initial stages of this essay, to Margie Kruppenbach for expert assistance with research, to Julia Finch for knowledgeable editing, to Cynthia Newman Bohn for meticulous copy editing, and to Alison M. Kettering for collegiality and encouragement. This paper is dedicated to the memory of lost friends and teachers, including Michael Baxandall, Jean Bony, Margarita Machilek, Harvey Stahl, and Barbara Lee Williams.

Debra Taylor Cashion is an independent scholar (PhD, U.C. Berkeley, 1994) specializing in medieval and Renaissance manuscripts and early printed books. She has a special interest in the descriptive and digital cataloging of medieval manuscripts and is presently a graduate student at the School of Information Science at the University of Pittsburgh.

\section{List of Illustrations}

Fig. 1 Nikolaus Glockendon, Missale Hallense of Albrecht of Brandenburg, 1524, Aschaffenburg, Hofbibliothek, Ms. 10, fols. 440v-441 (artwork in the public domain)

Fig. 2 Nikolaus Glockendon, Corpus Christi Procession, Missale Hallense of Albrecht of Brandenburg, 1524, Aschaffenburg, Hofbibliothek, Ms. 10, fol. 193v (artwork in the public domain)

Fig. 3 Nikolaus Glockendon, Coats of Arms of Albrecht of Brandenburg, Missale Hallense of Albrecht of Brandenburg, 1524, Aschaffenburg, Hofbibliothek, Ms. 10, fol. 07v (artwork in the public domain)

Fig. 4 Nikolaus Glockendon, The Trinity, Missale Hallense of Albrecht of Brandenburg, 1524, Aschaffenburg, Hofbibliothek, Ms. 10, fol. 22v (artwork in the public domain)

Fig. 5 Jakob Elsner, The Trinity, Kress Missal, 1513, Nuremberg, Germanisches Nationalmuseum, Hs. 113264, fol. 2v (artwork in the public domain)

Fig. 6 Nikolaus Glockendon, The Resurrection, Missale Hallense of Albrecht of Brandenburg, 1524, Aschaffenburg, Hofbibliothek, Ms. 10, fol. 153v (artwork in the public domain)

Fig. 7 Albrecht Dürer, The Resurrection (Large Passion), woodcut, 1510, Museum of Fine Arts, Boston, Bequest of Francis Bullard (Photo ( 2010 Museum of Fine Arts Boston)(artwork in the 
public domain)

Fig. 8 Hans Weiditz, The Flight Into Egypt, woodcut (Augsburg, Sigmund Grim \& Marx Wyrsung [sic], 1520), Cambridge University Library, SSS.54.36 (artwork in the public domain)

Fig. 9 Simon Bening, The Flight into Egypt, Prayer Book of Albrecht of Brandenburg, ca. 1525-30, Los Angeles, J. Paul Getty Museum, 83.ML.115 (formerly Ms. Ludwig IX 19), fol. 47v (artwork in the public domain)

Fig. 10 Nikolaus Glockendon, The Flight into Egypt, Passion Prayer Book of Albrecht of Brandenburg, ca. 1533/34, Modena, Biblioteca Estense, Ms. Est. 136 (formerly Ms. alpha.U.6.7), fol. 20 (artwork in the public domain)

Fig. 11 Gabriel Glockendon, The Flight into Egypt, Prayer Book of Albrecht of Brandenburg, 1537, Vienna, $\div$ sterreichische Nationalbibliothek, Cod. 1847, fol. 13v (artwork in the public domain)

Fig. 12 The Prophet Ezra, Codex Amiatinus, ca. 700, Florence, Biblioteca Medicea-Laurenziana, Ms. Am, fol. V (artwork in the public domain)

Fig. 13 Saint Matthew the Evangelist, Lindisfarne Gospels, ca. 698, London, British Library, Cotton MS Nero D.iv, fol. 25v (artwork in the public domain)

Fig. 14 Nikolaus Glockendon, Saint Veronica, Prayer Book of Jakob and Anna Sattler, ca. 1520, Munich, Bayerische Staatsbibliothek, Cgm, 9110, fol. 150v (artwork in the public domain)

Fig. 15 Nikolaus Glockendon, The Man of Sorrows, Prayer Book of Jakob and Anna Sattler, ca. 1520, Munich, Bayerische Staatsbiblothek, Cgm 9110, fol. 79v (artwork in the public domain)

Fig. 16 Albrecht Dürer, The Man of Sorrows with Arms Outstretched, engraving, ca. 1500, Museum of Fine Arts, Boston, Stephen Bullard Memorial Fund (Photo (c) 2010 Museum of Fine Arts Boston)(artwork in the public domain)

Fig. 17 Albrecht Dürer, Saint John Devouring the Book (Apocalypse), woodcut, ca. 1498, Museum of Fine Arts Boston, Gift of Edward P. Warren (Photo (C) 2010 Museum of Fine Arts Boston) (artwork in the public domain)

Fig. 18 Georg Stierlyn and Nikolaus Glockendon, Hours of the Virgin, Aschaffenburg, Hofbibliothek, Ms. 9, fols. 15v-16 (artwork in the public domain)

Fig. 19 Albrecht Dürer, The Flight into Egypt (Life of the Virgin), woodcut, ca. 1504, Museum of Fine Arts, Boston, Centennial Gift of Landon T. Clay (Photo (C) 2010 Museum of Fine Arts Boston)(artwork in the public domain)

Fig. 20 Giulio Clovio, The Flight into Egypt, Farnese Hours, New York, Morgan Library, M.69, fol. $42 \mathrm{v}$ (artwork in the public domain) 
Fig. 21 Nikolaus Glockendon, The Flight into Egypt, Hours of the Virgin, Aschaffenburg, Hofbibliothek, Ms. 9, fol. 32v (artwork in the public domain)

${ }^{\star}$ All translations are the author's unless otherwise indicated.

${ }^{1}$ For a complete catalog description and bibliography, see Ulrich Merkl, Buchmalerei in Bayern in der ersten Hälfte des 16. Jahrhunderts: Spätblüte und Endzeit einer Gattung (Regensburg: Schnell \& Steiner, 1999), 451-55. For further information on the manuscript (photographs of the binding) and patron, see Thomas Schauerte and Andreas Tacke, Der Kardinal: Albrecht von Brandenburg, Renaissancefürst und Mäzen, exh. cat., Stiftung Moritzburg (Regensburg: Schnell \& Steiner, 2006), 1 and 2: 315-21.

${ }^{2}$ Merkl, Buchmalerei in Bayern, 88-98; Ulrich Merkl, "Nikolaus Glockendons Leben und Werk," in Das Glockendon Gebetbuch: Biblioteca Estenbse Universitaria, alpha.U.6.7 (commentary volume to complete facsimile), ed. Regina Cermann et al. (Lucerne: Faksimile Verlag, 1998), 2: 47-74; and Debra Taylor Cashion, The Rowland Prayerbook of Nikolaus Glockendon: Manuscript Painting in the Golden Age of Nuremberg (PhD diss., University of California, Berkeley), 20-27.

${ }^{3}$ Nikolaus was the son of Georg Glockendon the Elder (d. 1514), the brother of Albrecht Glockendon (ca. 1495-1545), and the father of Gabriel (ca. 1515/20-ca. 1585) and Sebastian (ca. 1525/261555), all of whom painted illuminated manuscripts; Georg the Elder and Albrecht also worked in cartography, publishing, and prints. See Thomas Eser and Anja Grebe, Heilige und Hasen: Bücherschätze der Dürerzeit, exh. cat. (Nuremberg: Germanisches Nationalmuseum, 2008), 22-28, 76-79, 121-59; Merkl, Buchmalerei in Bayern, 72-73, includes a family tree.

${ }^{4}$ The artist's signature, in gold Roman capitals on a blue field, is on fol. 572 recto: "ICH NICKLAS GLOCKENDON / ZU NVRENBERG HAB DISSES / BHVCH ILVMINIERT VND / VOLENT

IM IAR / 1524." Ulrich Merkl has suggested that the figure of the harpist, who looks directly at the viewer, could be the artist himself, (Buchmalerei in Bayern, 89).

${ }^{5}$ G. W. H. Lochner, ed., Des Johann Neudörfer Schreib- und Rechenmeisters zu Nürnberg Nachrichten von Künstlern und Werkleuten daselbst aus dem Jahre 1547 (Vienna: W. Braumüller, 1875), 143.In the early 1500s, the cost of supporting a family of four for a year was approximately 35 gulden: Merkl, Buchmalerei in Bayern, 187, 234-36. For other fees paid to Nuremberg artists, see Rainer Kahsnitz and William D. Wixom, Gothic and Renaissance Art in Nuremberg, 1300-1550, exh. cat. (New York: Metropolitan Museum of Art, 1986), 51-60.

${ }^{6}$ Lochner, Johann Neudörfer, 143.

${ }^{7}$ Eser and Grebe, Heilige und Hasen, 22-24 and several catalogue entries; Merkl, Buchmalerei in Bayern, 88-98.

${ }^{8}$ Peter Strieder, Meister um Albrecht Dürer, exh. cat. (Nuremberg: Germanisches Nationalmuseum, 1961), 15; Glockendon is included on pages 94-96; see also Kahsnitz and Wixom, Gothic and Renaissance Art (this 1986 exhibition of Nuremberg art omitted works by Nikolaus Glockendonóa welcome correction to this oversight was the 2008 exhibition at Nuremberg: Eser and Grebe, Heilige und Hasen.

${ }^{9}$ For Sebald Beham et al., see Alison G. Stewart, Before Bruegel: Sebald Beham and the Origins of 
Peasant Festival Imagery (Burlington, VT: Ashgate, 2008); Alison G. Stewart, The First 'Peasant Festivals': Eleven Woodcuts Produced in Reformation Nuremberg by Barthel and Sebald Beham and Erhard Schön, ca. 1524-1535 (PhD diss., Columbia University, 1986); and Emil Waldman, Die Nürnberger Kleinmeister (Leipzig: Klinkhardt \& Biermann, 1910).

${ }^{10}$ Joseph Leo Koerner, The Moment of Self-Portraiture in German Renaissance Art (Chicago: University of Chicago Press, 1996), 203-23.

${ }^{11}$ William M. Conway, The Literary Remains of Albrecht Dürer (Cambridge, UK: University Press, 1889), 128; see also Hans Rupprich, Dürer Schriftlicher Nachlass (Berlin: Deutsch Verein für Kunstwissenschaft, 1956), 1:95-96.; the commission of the Missale Hallense is also documented by correspondence from the same period between Cardinal Albrecht and Caspar Nützel of Nuremberg: Paul Redlich, Der Cardinal Albrecht von Brandenburg und das neue Stift zu Halle, 1520-1541 (Mainz: Franz Kirchheim, 1900), 221.

${ }^{12}$ Eser and Grebe, Heilige und Hasen, 23-24; Schauerte and Tacke, Der Kardinal, 1:134-35; 2:32829; and Merkl, Buchmalerei in Bayern, 454. The drawing and miniature are reproduced in all of these sources.

${ }^{13}$ The recently published Kiefhaber Prayer Book is another manuscript by Glockendon with miniatures that closely depend on Dürer's compositions: Eser and Grebe, Heilige und Hasen, 78-79; Anja Grebe, "Ein Gebetbuch aus Nürnberg im Germanischen Nationalmuseum und das Frühwerk von Nikolaus Glockendon," Anzeiger des Germanischen Nationalmuseums (2005), 97-120. ${ }^{14}$ Merkl, Buchmalerei in Bayern, 453.

${ }^{15}$ James H. Marrow, "Nikolaus Glockendon and Simon Bening: German Copies of the Evangelist Portraits in Bening's Stockholm Book of Hours," Nationalmuseum Bulletin, Stockholm 7, no. 2 (1983): 93-101.

${ }^{16}$ Eser and Grebe, Heilige und Hasen, 21-22, 11-115; Merkl, Buchmalerei in Bayern, 58-62; and Kahsnitz and Wixom, Gothic and Renaissance Art, 186-97.

${ }^{17}$ Ulrich Steinmann, "Das Andachts-Gebetbuch vom Leiden Christi des Cardinals Albrecht von Brandenburg," Aachener Kunstblätter 29 (1964): 139-77; Nikolaus Glockendon's and Gabriel Glockendon's manuscripts have been produced in facsimile: Regina Cermann, ed., Das Glockendon-Gebetbuch (see note 2 above), and Dagmar Thoss, Gebetbuch für Kardinal Albrecht von Brandenburg: Gabriel Glockendon, Nürnberg 1536/37 (Münster: Biblioteca Rara, 2008); for Bening's manuscript, see Thomas Kren and Scot McKendrik, Illuminating the Renaissance: The Triumph of Flemish Manuscript Painting in Europe, exh. cat. (Los Angeles: J. Paul Getty Museum, 2003), 456-57.

${ }^{18}$ All three illuminators add images to the pictorial cycle of the printed exemplar, placing them in the exact same location in the text. Glockendon's manuscript combines miniatures and historiated borders that are separated between facing pages in Bening's version. For an analysis of the miniatures by Nikolaus Glockendon, see Eberhard König, “Text und Bild im Gebetbuch in Modena: Die Vorgabe des Autors und die Gestaltung durch Schreiber und Maler," in Das Glockendon-Gebetbuch (see note 2 above), 97-153.

${ }^{19}$ Jane S. Peters, "Early Drawings by Augustin Hirschvogel," Master Drawings 17, no. 4 (Winter 1979): 359-92, 429-35; see also John Rowlands and Giulia Bartrum, Drawings by German Artists and Artists from German-Speaking Regions of Europe in the Department of Prints and Drawings in the British Museum (London: British Museum Press, 1993), 1:132-34; 2: plates 192-93.

${ }^{20}$ Michael Baxandall, The Limewood Sculptors of Renaissance Germany (New Haven: Yale University Press, 1980), 123-27. 
${ }^{21}$ Baxandall, Limewood Sculptors, 125.

${ }^{22}$ Baxandall, Limewood Sculptors, 125.

${ }^{23}$ Joseph Leo Koerner, "Albrecht Dürer, A Sixteenth-Century Influenza," Albrecht Dürer and His Legacy: The Graphic Work of a Renaissance Artist, exh. cat., British Museum, ed. Guilia Bartrum (Princeton: Princeton University Press, 2002), 18-38.

${ }^{24}$ Robert Suckale, “Die Zeit der Gotik: Die Regensburger Buchmalerei von 1250 bis 1350," in Regensburger Buchmalerei: Von frühkarolingischer Zeit bis zum Ausgang des Mittelalters, exh. cat., Bayerische Staatsbibliothek und der Museen der Stadt Regensburg, ed. Florentine Mütherich and Karl Dachs (Munich: Prestel Verlag, 1987), 80.

${ }^{25}$ Cyril Mango, The Art of the Byzantine Empire, 312-1453: Sources and Documents (Toronto: University of Toronto Press, 1986), 41-42. See also Richard E. Spear, "Notes on Renaissance and Baroque Originals and Originality," Retaining the Original: Multiple Originals, Copies, and Reproductions, Studies in the History of Art 20, Center for Advanced Study in the Visual Arts Symposium Papers VII (Washington, DC: National Gallery of Art, 1989), 97.

${ }^{26}$ Richard Krautheimer, "Introduction to an 'Iconography of Medieval Architecture," Journal of the Warburg and Courtauld Institutes 5 (1942): 16. doi:10.2307/750446

${ }^{27}$ Richard Krautheimer, "Introduction to an 'Iconography of Medieval Architecture," 15-16.

${ }^{28}$ J. A. Tasioulas, "Between Doctrine and Domesticity: The Portrayal of Mary in the N-Town Plays," in Medieval Women and their Communities, ed. Diane Watt (Toronto: University of Toronto Press, 1997), 22-223.

${ }^{29}$ Magdalene Gärtner, Römische Basiliken in Augsburg: Nonnenfrömmigkeit und Malerei um 1500, Schwäbische Geschitchtsquellen und Forschungen 23 (Augsburg: Wissner, 2002); Pia F. Cuneo, "The Basilica Cycle of Saint Katherine's Convent: Art and Female Community in Early-Renaissance Augsburg," Women's Art Journal 19, no. 1 (Spring-Summer 1998): 21-

25. doi:10.2307/1358650

${ }^{30}$ Walter Benjamin, “The Work of Art in the Age of Mechanical Reproduction," in Illuminations, ed. Hannah Arendt (New York: Schocken Books, 1978), 217-51.

${ }^{31}$ Hans Belting, Likeness and Presence: A History of the Image before the Era of Art (Chicago: University of Chicago Press, 1994), 60.

${ }^{32}$ Otto von Simson, The Gothic Cathedral: Origins of Gothic Architecture and the Medieval Concept of Order (Princeton: Princeton University Press, 1974), 166.

${ }^{33}$ Nine Miedema, "Following the Footsteps of Christ: Pilgrimage and Passion Devotion," in The Broken Body: Passion Devotion in Late Medieval Culture, ed. A. A. MacDonald, H. N. B. Ridderbos, and R. M. Schlusemann (Groningen: Egbert Forsten, 1998), 73-92.

${ }^{34}$ For a classic introduction to medieval manuscripts as books, see Barbara Shailor, The Medieval Book, exh. cat., Beinecke Library (New Haven: Yale University, 1988); for a historical survey of illuminated manuscripts see Christopher De Hamel, A History of Illuminated Manuscripts (London: Phaidon, 1994).

${ }^{35}$ For a study of a famously copied manuscript, see Koert van der Horst, William Noel, and Wilhelmina C. M. Wüstefeld., The Utrecht Psalter in Medieval Art: Picturing the Psalms of David, exh, cat., Museum Catharijneconvent, Utrecht (Westrenen: Hes, 1996).

${ }^{36}$ De Hamel, A History of Illuminated Manuscripts, 14-21.

${ }^{37}$ For a recent study of the Codex Amiatinus and further bibliography, see Celia Chazelle, "Christ and the Vision of God: The Biblical Diagrams of the Codex Amiatinus," in The Mind's Eye: Art and Theological Argument in the Middle Ages, ed. Jeffrey F. Hamburger and Anne-Marie 
Bouché (Princeton: Princeton University Press, 2006), 84-111.

${ }^{38}$ For a manifesto against this practice, see Lee Patterson, "On the Margin: Postmodernism, Ironic History, and Medieval Studies," Speculum, 65, no. 1 (January 1990): 87-108. doi:10.2307/2864473 ${ }^{39}$ See for example, James Snyder, Medieval Art: Painting, Sculpture, Architecture, 4th-14th Century (New York: Harry N. Abrams, 1989), 185-86. See also Jonathan J. G. Alexander, "Facsimiles, Copies, and Variations: The Relationship to the Model in Medieval and Renaissance European Manuscripts," in Retaining the Original (see note 25 above), 61-72. Alexander (p. 71) cites the scholarship on the Codex Amiatinus.

${ }^{40}$ For a revisionist discussion of imitation in classical sculpture see Miranda Marvin, "Copying in Roman Sculpture: The Replica Series," in Retaining the Original, 29; Miranda Marvin, "Roman Sculptural Reproductions or Polykleitos: The Sequel," in Sculpture and Its Reproductions, ed. Anthony Hughes and Erich Ranfft (London: Reaktion Books, 1997), 7-28.

${ }^{41}$ For an examination of this image in medieval pious practice, see Jeffrey Hamburger, The Visual and the Visionary: Art and Spirituality in Late Medieval Germany (Cambridge, MA: Zone Books, 1998), 317-82. For a history of this image, see Belting, Likeness and Presence, 208-24.

${ }^{42}$ Munich, Bayerische Staatsbibliothek, Cgm 9110, fol. 151ff; for a description of the manuscript, see Merkl, Buchmalerei in Bayern, 439-41, and Cashion, Rowland Prayerbook, 32-178.

43 "Gegrussett seist du heiliges angesicht unsers erlossers, in dem da scheinet die gestalt des gotliche scheins, eingetruckt in ein tuchlein des schne gelanz, gebeen fronica unntter einem zaichenn der lieb...." (Munich, Cgm 9110, fols. 151-153): Cashion, Rowland Prayerbook, 118.

${ }^{44} \mathrm{R}$. Howard Bloch, Etymologies and Genealogies: A Literary Anthropology of the French Middle Ages (Chicago: University of Chicago Press, 1983), 37-44; Carolyn Dinshaw, Chaucer's Sexual Poetics (Madison: University of Wisconsin Press, 1989), 3-5.

${ }^{45}$ Mosche Barasch, Theories of Art from Plato to Winckelmann (New York: New York University Press, 1985), 56.

${ }^{46}$ Jon F. Dechow, Dogma and Mysticism in Early Christianity: Epiphanius of Cyprus and the Legacy of Origen (Macon, GA: Mercer University Press, 1988), 307.

47 “...zuschawenn das angesicht, Da ist Chriti clar...." (Munich, Cgm 9110, fols. 151-153): Cashion, Rowland Prayerbook, 120.

${ }^{48}$ Peter Parshall, "Imago Contrafacta: Images and Facts in the Northern Renaissance," Art History 16, no. 4 (December 1993): 554-79.

${ }^{49}$ For the icon and its iconographic tradition, see Bernard Ridderbos, "The Man of Sorrows: Pictorial Images and Metaphorical Statements," in The Broken Body: Passion Devotion in Late-Medieval Culture (note 33 above), 145-81.

${ }^{50}$ Eser and Grebe, Heilige un Hasen, 134-35; Merkl, Buchmalerei in Bayern, 439-41; Katharina Urch and Karin Schneider, Gebetbuch von Nikolaus Glockendon für Jakob Welser den flteren, Patrimonia 70 (Munich: KulturStiftung der Länder, 1993), 37-40; Cashion, Rowland Prayerbook, 97-103. In the Munich study, the patronage of the manuscript was erroneously assigned to the Welser family, based on a hypothetical discussion in my doctoral dissertation, 162-76. Ulrich Merkl fortunately discovered the dispersed frontispiece with the Sattler family coat of arms in the British Museum (Dept. of Prints and Drawings, 5218-69). The name "Rowland" was taken from a recent owner of the manuscript.

51 "Welcher Mensch vor dem pilde d[e]s Mann Nennt die parmherzigkeit gottes, spricht oder pet drei pater noster unnd so vill ave maria, der hatt xxxiiii tausset unnd xl Jar ablass Bestetigt vom pabst clementin. [U]nd wann die waffen xpi dar bei sein, so ist der ablass zwifach. Von aim 
yetliche[n] Waffenn ist besunder ablass; darnach sprich das gepett mit andacht, und dz ablass ist gefunden worden, von[n] Dem wirdigen vater Nikolaus, abt unser frawen munster zu florenz." (Munich, Cgm 9110, fols. 151-153): Cashion, Rowland Prayerbook, 97-98.

${ }^{52}$ Henri DeFoer, "Images as Aids for Earning the Indulgences of Rome," in Tributes in Honor of James Marrow: Studies in Painting and Manuscript Illumination of the Late Middle Ages and Renaissance, ed. Jeffrey F. Hamburger and Anne S. Korteweg (Turnhout, Belgium: Brepols, 2006), 163-71.

${ }^{53} \mathrm{See}$, for example, the billowed loincloth of the Crucifixion in the Kress Missal by Jacob Elsner, 1513: Kahsnitz and Wixom, Gothic and Renaissance Art, 196-97.

${ }^{54}$ As the cult of the Passion grew in the fourteenth century, the number of venerated relics increased. In 1496, the relic of the loincloth drew 142,000 pilgrims to Aachen; see Jeffrey Chipps Smith, German Sculpture of the Later Renaissance, c. 1520-1580: Art in an Age of Uncertainty (Princeton: Princeton University Press, 1994), 14. An image of the Arma Christi from the Passional of the Abbess Kunigunde (1314-21) of the convent of St. George in Prague includes the loincloth; see Gertrud Schiller, Iconography of Christian Art (Greenwich, CT: New York Graphic Society, 1972), 2:190-92, fig. 657.

${ }^{55}$ Gerald R. Bruns, "The Originality of Texts in a Manuscript Culture," Comparative Literature 32, no. 2 (Spring 1980): 113. This essay also exists in a revised version in: Gerald R. Bruns, Inventions: Writing, Textuality, and Understanding in Literary History (New Haven: Yale University Press, 1982), 44-59. doi:10.2307/1770504

${ }^{56}$ Bruns, "Originality of Texts," 125.

${ }^{57}$ Bruns, "Originality of Texts," 116.

${ }^{58}$ Bruns, "Originality of Texts," 125.

${ }^{59}$ Bruns, "Originality of Texts," 126.

${ }^{60}$ James Douglas Farquhar and Sandra Hindman, Pen to Press: Illustrated Manuscripts and Printed Books in the First Century of Printing, exh. cat., Art Department Gallery, University of Maryland (College Park: University of Maryland Press, 1977), 65.

${ }^{61}$ Farquhar and Hindman, Pen to Press, 70-71.

${ }^{62}$ Susan Dackerman, Painted Prints: The Revelation of Color, exh. cat., Baltimore Museum of Art (University Park: Penn State University Press, 2002), 11-16.

${ }^{63}$ Julien Chapuis, Tilman Riemenschneider: Master Sculptor of the Late Middle Ages, exh. cat. (Washington, D.C.: National Gallery of Art, 1999), , 216; Baxandall, Limewood Sculptors, 261. ${ }^{64}$ Griselda's tale was widely circulated, translated and retold by Chaucer as well as Christiane de Pizan. Dinshaw, Chaucer's Sexual Poetics, 132ff.; Christine de Pizan, The Book of the City of Ladies, trans. Earl Jeffrey Richards (New York: Persea Books, 1982), 170-76.

${ }^{65}$ Bruns, "Originality of Texts," 117 . Chaucer translated the phrase, perhaps mistakenly transcripted from Petrarch, as "with heigh stile." See Germaine Dempster, "Chaucer's Manuscript of Petrarch's Version of the Griselda Story." Modern Philology 41, no. 1 (August 1943): 6-16. doi:10.1086/388598

${ }^{66}$ Max Reinhart, ed., Early Modern German Literature, 1350-1700 (Rochester, NY: Camden House, 2007), 602-3, 779-82; Albrecht Classen, "Heinrich Steinhöwel," in German Writers of the Renaissance and Reformation 1280-1580, ed. James Hardin and Max Reinhart, Dictionary of Literary Biography, vol. 179 (Detroit: Gale Research, 1997), 276-80; Ursula Hess, Heinrich Steinhöwels 'Griseldis': Studien zur Text- und Überlieferungsgeschichte einer frühhumanistischen Prosanovelle (Munich: C. H. Beck, 1975). 
${ }^{67}$ Adelbert Keller, ed., Translationen von Niclas von Wyle (Hildesheim: G. Olms, 1967); Eric John Morall, Aeneas Silvius Piccolomini (Pius II) and Niklas von Wyle: The Tale of Two Lovers Eurialus and Lucretia (Amsterdam: Rodopi, 1988); Reinhart, Early Modern German, 602-3, 786-90; John L. Flood, "Niklas von Wyle," in German Writers of the Renaissance and Reformation 1280-1580 (note 66 above), 332-37. Wyle's first name is spelled "Niclas" and "Niklas" in the literature.

${ }^{68}$ Keller, Translationen, 79. A controversy exists among modern scholars about whether this preface indicates that Wyle produced a translation of Griselda. Hess, Heinrich Steinhöwel's 'Griseldis,' $10-11$.

${ }^{69}$ Keller, Translationen, 9; Reinhart, Early Modern German, 789; Flood, "Niklas von Wyle," 334. I thank Albrecht Classen at the University of Arizona for generous advice about this subject. ${ }^{70}$ Albert Kapr, Johannes Gutenberg: The Man and his Invention (Brookfield, VT: Scolar Press, 1996), 158-71.

${ }^{71}$ Albert Kapr also points out that a Bible was a more practical text to print than a missal, a text for which there was also a great demand, because a missal required various hierarchies of text and thus several different sizes of type. Kapr, Johannes Gutenberg, 153-54.

${ }^{72}$ For example, illuminators were among the one hundred plus journeymen, including typesetters, press operators, editors, compositors, and binders, that the Nuremberg printer and publisher Anton Koberger employed in his shop. Lochner, Johann Neudörfer, 173.

${ }^{73}$ Eberhard König, "The Influence of the Invention of Printing on the Development of German Illumination," in Manuscripts in the Fifty Years after the Invention of Printing, ed. J. B. Trapp (London: Warburg Institute, 1983), 85-94.

${ }^{74}$ König, "Influence," 87.

${ }^{75}$ König, "Influence," 88 . The emphasis in the quote is mine.

${ }^{76}$ James H. Marrow, "A Book of Hours from the Circle of the Master of the Berlin Passion: Note on the Relationship between Fifteenth-century Manuscript Illumination and Printmaking in the Rhenish Lowlands," Art Bulletin 60 (1978): 590-616. doi:10.2307/3049840

${ }^{77}$ Marrow also considers an alternative attribution to an engraver, perhaps the Master of the Berlin Passion himself. Marrow, "Book of Hours," 23.

${ }^{78}$ Farquhar and Hindman, Pen to Press, 101-56.

${ }^{79}$ Lochner, Johann Neudörfer, 140-41. A discussion of the city records of the Glockendon family circumstances are appended to Neudörfer's account by Lochner, Johann Neudörfer, 140-44. For Briefmaler, see Dackerman, Painted Prints, 15-26; for an example of a Wappenbrief, see Eser and Grebe, 144-45.

${ }^{80}$ Eser and Grebe, Heilige und Hasen, 121-27; Merkl, Buchmalerei in Bayern, 62-70, 390-98.

${ }^{81}$ Albrecht inherited his father's shop and woodblocks and worked as a publisher of prints as well as an illuminator. Eser and Grebe, Heilige und Hasen, 140-47; Merkl, Buchmalerei in Bayern, 70-83, 398-427. Nikolaus opened his own shop and worked mostly as an illuminator of liturgical books and prayer books, although he also decorated some official documents for the city, see Eser and Grebe, Heilige und Hasen, 128-29.

${ }^{82}$ James H. Marrow, "Nikolaus Glockendon and Simon Bening: German Copies of the Evangelist Portraits in Bening's Stockholm Book of Hours," Nationalmuseum Bulletin, Stockholm 7, no. 2 (1983): 93-101.

${ }^{83}$ Marrow, “Nikolaus Glockendon,” 99.

${ }^{84}$ In the year 1468 at Rome, one could purchase a printed book for about the price of just the blank velum of a comparable manuscript: Curt F. Bühler, The Fifteenth Century Book: The Scribes, 
the Printers, the Decorators (Philadelphia: University of Pennsylvania Press, 1960), 39.

${ }^{85}$ Better known as a printmaker, Beham painted single-leaf miniatures, coats of arms, and a table top for Albrecht of Brandenburg: Alison G. Stewart, Before Bruegel, chap. 1 and pp. 15-27, fig. 1.7; the so-called Behamsches Gebetbuch (Aschaffenburg Hofbibliothek, Ms. 8), dated 1531 and made for Cardinal Albrecht, includes tipped-in miniatures by Beham and Nikolaus Glockendon: Schauerte and Tacke, Der Kardinal, 1:113-20; Alfons Biermann, "Die Miniaturen Handschriften de Kardinals Albrecht von Brandenburg 1514-1545," Aachener Kunstblätter des Museumvereins 46 (1975) 233-38; and Merkl, Buchmalerei in Bayern, 372-75, 470-72.

${ }^{86}$ Biermann, “Die Miniaturen Handschriften," 213-21. For Aschaffenburg Ms. 9, see Merkl, Buchmalerei in Bayern, 468-69.

${ }^{87}$ Nikolaus Glockendon revealed the family acumen for business when, remarkably, he produced an illuminated version of Luther's New Testament for Duke Johann Friedrich of Saxony in 1524, the same year he finished the Missale Hallense for Cardinal Albrecht. Duke Friedrich's manuscript, now in Wolfenbüttel (Cod. Guelf. 25.13,14 Extravangantes), is also signed by the artist (NICKLAS GLOCKENDON ILVMINIST ZV NVRENBERG 1524), who seemed to hedge his bets regarding the Reformation of the church and the state of his soul: Merkl, Buchmalerei in Bayern, 456-60.

${ }^{88}$ Erwin Panofsky, The Life and Art of Albrecht Dürer (Princeton; Princeton University Press, 1971), 44.

${ }^{89}$ Dackerman, Painted Prints, 15-16.

${ }^{90}$ Eser and Grebe, Heilige und Hasen, 45-87.

${ }^{91}$ Matthias Mende, Anna Scherbaum, and Rainer Schoch, Die Drei Grossen Bücher (Nördlingen: Alfons Uhl, 2001). Horst Appuhn, Die Drei Grossen Bücher (Dortmund: Harenberg, 1986), also reproduces the "three great books" but in smaller scale.

${ }_{92}$ The instructional books include the Four Books on Human Proportion and the Course in the Art of Measurement. For a facsimile of the former, see Albrecht Dürer, Vier Bücher von Menschlicher Proportion (London: G. M. Wagner, 1970); see also Panofsky, Life and Art of Albrecht Dürer, 242-84. For a facsimile of the Small Passion, see Horst Appuhn, Die kleine Passion von Albrecht Dürer (Dortmund: Harenberg, 1985); for an eye-opening study of the Small Passion text, see David Hotchkiss Price, Albrecht Dürer's Renaissance: Humanism, Reformation, and the Art of Faith (Ann Arbor: University of Michigan Press, 2003), 169-93. For the Prayer Book of Maximilian, see Larry Silver, Marketing Maximilian: The Visual Ideology of a Holy Roman Emperor (Princeton: Princeton University Press, 2008), 120-30; For the Salus Animae, see Panofsky, Life and Art of Albrecht Dürer, 96.

${ }^{93}$ Eser and Grebe, Heilige und Hasen, 46-47; Kahsnitz and Wixom, Gothic and Renaissance Art, 272-74.

${ }^{94}$ Panofsky, Life and Art of Albrecht Dürer, 51.

95 "Heus to insidiator ac alieni laboris \& ingenii surreptor. Ne manus temerarias his nostris operibus inicias ca[v]e. Scias eni[m] a gloriosissimo Romanoru[m] imperatore Maximiliano, nobis $\mathrm{co}[\mathrm{n}]$ cessum esse, ne quis suppositiciis formis has imagines imprimere seu impressas per imperii limites vendere audeat. Q[uod] si per co[n]temtum se avarici[am] crimen[am] fecus fecereis, post bonorum conficascionem tibi maximum periculum subeundum esse certissime scias." Taken from the 1511 edition of the Small Passion: Horst Appuhn, Die kleine Passion, 83. Appuhn offers a comparable translation into German on page 137.

${ }^{96}$ Koerner, The Moment of Self-Portraiture, 213-14; see also Koerner, "Albrecht Dürer: A Six- 
teenth-Century Influenza," 18-38.

${ }^{97}$ Harold Bloom, The Anxiety of Influence: A Theory of Poetry (New York: Oxford University Press, 1973).

${ }^{98}$ In humanist critical writing, the pairing of these terms or equivalent substitutes was common. Michael Baxandall, Giotto and the Orators (Oxford: Oxford University Press, 1971), 15-17.

${ }^{99}$ Here I use the term counterfeit in the modern sense of the word. I think it best describes Dürer's use of the word suppositiis (substituted, especially falsely substituted). Koerner's translation, "spurious," is also fine.

${ }^{100}$ Rainer Kahsnitz, ed, Veit Stoss in Nürnberg, exh. cat., Germanisches Nationalmuseum (Munich: Deutscher Kunstverlag, 1983), 352; M. Lossnitzer, Veit Stoss (Leipzig, J. Zeitler, 1912), Appendix II, no. 124. The German translation of the privilege by Horst Appuhn agrees with mine: Appuhn translates suppositiis formis as "gefälschten Stöcken": Appuhn, Die kleine Passion, 137.

${ }^{101}$ Jeffrey Chipps Smith, Nuremberg: A Renaissance City, 1500-1618, exh. cat., Huntington Gallery, University of Texas (Austin: University of Texas Press, 1983), 224-33.

${ }^{102}$ Maryan Ainsworth and Keith Christiansen, From Van Eyck to Bruegel: Early Netherlandish Painting in the Metropolitan Museum of Art, exh. cat. (New York: Metropolitan Museum of Art, 1998), 205-6.

${ }^{103}$ Parshall, "Imago Contrafacta," 567-70; Koerner, Moment of Self-Portraiture, 215-18.

${ }^{104}$ J. C. Smith, German Sculpture, 47; Kahsnitz and Wixom, Gothic and Renaissance Art, 59-60.

${ }^{105}$ In 1509 Albrecht Dürer paid 275 florins (= gulden) for his house: Jane Campbell Hutchison, Albrecht Dürer: A Biography (Princeton: Princeton U. Press, 1990), 98.

${ }^{106}$ Baxandall, Giotto and the Orators, 15-17. In the posthumously published Four Books on Human Proportion, the privilege granted to Agnes Dürer uses the terms Fleiss (diligence) and Erfindung (inventiveness). Albrecht Dürer, Vier Bücher von Menschlicher Proportion(London: G. M. Wagner, 1970), fol. Ziiii, line 7.

${ }^{107}$ Giorgio Vasari, Lives of the Most Eminent painters, Sculptors, and Architects, trans. Gaston du C. De Vere (London: Macmillan, 1912-14), 6:96. (The Lives was first published in 1550 but enlarged for the second edition of 1568.) For works by Marcantonio, see Innis H. Shoemaker, The Engravings of Marcantonio Raimondi, exh. cat. (Lawrence, KS: Spencer Museum of Art, 1981).

${ }^{108}$ Koerner, Moment of Self-Portraiture, 209.

${ }^{109}$ Mark Jones, Fake? The Art of Deception (Berkeley, University of California Press, 1990), 120-21.

${ }^{110}$ Lisa Pon, Raphael, Dürer, and Marcantonio Raimondi: Copying and the Italian Renaissance

Print (New Haven: Yale University Press, 2004), 62.

${ }^{111}$ Pon, Raphael, 64.

${ }^{112}$ On Beham's Kermis at Erlangen, ca. 1535, the privilege reads: "By favor \& privilege of his imperial majesty: Let no one dare to print the present work, Under pain and payment of ten marks of pure gold. Albrecht Glockendon Illuminist" [Imperatoris Maiestatus gratia \& privilegio: ne quis in tipis presens opus Imprimere ausit: sub penis et tensuris Decem Marcarum auri purissimi. Albrecht Glockendon Illuminist]: Alison Stewart, Before Bruegel, 142-43 (her translation). Albrecht and Nikolaus Glockendon each refer to himself in various manuscripts as "Illuminist." My experience does not support the interpretation that the term illuminist literally meant "publisher" (suggested in Alison Stewart, The First Peasant Festivals [see note 10 above], 379-84). Dürer, for example, was a publisher but not an illuminist, a term regularly used to refer to manuscript illuminators in primary sources such as Neudörfer's Nachrichten and city records: Theodor Hampe, ed., Nürnberger Ratsverlässe über Kunst und Künstler im Zeitalter der Spätgotik und 
Renaissance (Vienna: Karl Graeser, 1904), vols. 1-3; see also Dackerman, Painted Prints, 15-26.

${ }^{113}$ Christine Vogt, Das druckgraphische Bild nach Vorlagen Albrecht Dürers (Munich: Deutscher Kunstverlag, 2008), 77-94.

${ }^{114}$ Evelyn Lincoln, The Invention of the Italian Renaissance Printmaker (New Haven: Yale University Press, 2000), 10.

${ }^{115}$ Webster Smith, The Farnese Hours (New York: George Braziller, 1976).

${ }^{116}$ Gerald Strauss, Nuremberg in the Sixteenth Century (Bloomington: Indiana University Press, 1976), 137.

${ }^{117}$ Two sallets (helmets) of ca. 1480-90, attributed to Hans Grünewalt, include Nuremberg city marks and one includes a master's mark: Kahsnitz and Wixom, Gothic and Renaissance Art, 204. A ca. 1535 crinet (neckguard for a horse) by the Nuremberg armorer Valentin Siebenbürger includes his master's mark, a jousting helmet flanked by his initials, as well as the city's coat of arms and a letter $N$ inside a pearled circle: Stuart W. Pyhrr, Donald J. LaRocca, and Dirk H. Breiding, The Armored Horse in Europe, 1480-1620, exh. cat. (New York: Metropolitan Museum of Art, 2005), 44-45. I am grateful to Dirk Breiding of the Metropolitan Museum for generous advice concerning the regulation and use of marks in Nuremberg armor.

${ }^{118}$ For examples of the reverse $N$ in Nuremberg goldsmith's work see Kahsnitz and Wixom, Gothic and Renaissance Art, 214-16, 222-27. See also Marc Rosenberg, Der goldschmiede Merkze-

ichen (Frankfurt: Frankfurter Verlags-Anstalt, 1922-28), vol. 3, 13-24.

${ }^{119}$ Strauss, Nuremberg in the Sixteenth Century, 97-98; J. C. Smith, Nuremberg: A Renaissance City, 46-47.

${ }^{120}$ J. C. Smith, Nuremberg: a Renaissance City, 46-47; see also Dackerman, Painted Prints, 20-24.

${ }^{121}$ Nuremberg city records preserve an incident in which the town council enforced Dürer's monogram against a foreign artist who sold prints in front of the town hall. Nuremberg also required all heads of workshops to be citizens of Nuremberg: J. C. Smith, Nuremberg, 47; Koerner, Moment of Self-Portraiture, 209.

${ }^{122}$ Lochner, Johann Neudörfer. For biographical information about Neudörfer, see The Dictionary of Art, ed. Jane Turner (New York: Grove's Dictionaries, 1996), s.v., "Neudörfer, Johann” (by Jeffrey Chipps Smith).

${ }^{123}$ Neudörfer published several manuals about writing and contributed inscriptions to some of Dürer's projects: J. C. Smith, Nuremberg, 253; Albert Kapr, Johann Neudörffer d. f., der grosse Schreibmeister der deutschen Renaissance (Leipzig: Otto Harrassowitz, 1956).

${ }^{124}$ Lochner, Johann Neudörfer, 10.

${ }^{125}$ Lochner, Johann Neudörfer, 155.

${ }^{126}$ Lochner, Johann Neudörfer, 115.

${ }^{127}$ Lochner, Johann Neudörfer, 178-79.

${ }^{128}$ Lochner, Johann Neudörfer, 187-88.

${ }^{129}$ Lochner, Johann Neudörfer, 116. Such works became sought after components of the Renaissance Kunstkammer. For a study that includes kinetic nature casts in Kunstkammer collections, see Horst Bredekamp, The Lure of Antiquity and the Cult of the Machine: The Kunstkammer and the Evolution of Nature, Art, and Technology (Princeton: Markus Wiener, 1995).

${ }^{130}$ Lochner, Johann Neudörfer, 126.

${ }^{131}$ Pamela H. Smith, The Body of the Artisan: Art and Experience in the Scientific Revolution (Chicago: University of Chicago Press, 2004), 74-76; Gerhard Bott, ed., Wenzel Jamnitzer und die Nürnberger Goldschmiedekunst 1500-1700, exh. cat., Germanisches Nationalmuseum (Munich: 
Klinkhardt \& Biermann, 1985), 221-27, 410-12.

${ }^{132}$ Pamela H. Smith and Tony Beentjes, "Nature and Art, Making and Knowing: Reconstructing Sixteenth-Century Life-Casting Techniques" Renaissance Quarterly 63 (Spring 2010): 142. doi:10.1086/652535

\section{Bibliography}

Ainsworth, Maryan, and Keith Christiansen. From Van Eyck to Bruegel: Early Netherlandish Painting in the Metropolitan Museum of Art. Exh. cat. New York: Metropolitan Museum of Art, 1998.

Alexander, Jonathan J. G. "Facsimiles, Copies, and Variations: The Relationship to the Model in Medieval and Renaissance European Manuscripts." In Retaining the Original: Multiple Originals, Copies, and Reproduction, 61-72. Studies in the History of Art 20. Center for Advanced Study in the Visual Arts Symposium Papers VII. Washington, D.C.: National Gallery of Art, 1989.

Appuhn, Horst. Die Drei Grossen Bücher. Dortmund: Harenberg, 1986.

Barasch, Mosche. Theories of Art from Plato to Winckelmann. New York: New York University Press, 1985.

Baxandall, Michael. Giotto and the Orators. Oxford: Oxford University Press, 1971.

Baxandall, Michael. The Limewood Sculptors of Renaissance Germany. New Haven: Yale University Press, 1980.

Benjamin, Walter. “The Work of Art in the Age of Mechanical Reproduction." In Illuminations, 217-51. Edited by Hannah Arendt. New York: Schocken Books, 1978.

Belting, Hans. Likeness and Presence: A History of the Image before the Era of Art. Chicago: University of Chicago Press, 1994.

Biermann, Alfons. "Die Miniaturen Handschriften de Kardinals Albrecht von Brandenburg 15141545.” Aachener Kunstblätter des Museumvereins 46 (1975): 15-309.

Bloch, R. Howard. Etymologies and Genealogies: A Literary Anthropology of the French Middle Ages. Chicago: University of Chicago Press, 1983.

Bloom, Harold. The Anxiety of Influence: A Theory of Poetry. New York: Oxford University Press, 1973.

Bott, Gerhard, ed. Wenzel Jamnitzer und die Nürnberger Goldschmiedekunst, 1500-1700. Exh. cat. (Germanisches Nationalmuseum). Munich: Klinkhardt \& Biermann, 1985.

Bredekamp, Horst. The Lure of Antiquity and the Cult of the Machine: The Kunstkammer and the 
Evolution of Nature, Art, and Technology.Princeton: Markus Wiener, 1995.

Bruns, Gerald R. "The Originality of Texts in a Manuscript Culture." Comparative Literature 32, no. 2 (Spring 1980): 113-29.

Bruns, Gerald R. Inventions: Writing, Textuality, and Understanding in Literary History. New Haven: Yale University Press, 1982. doi:10.2307/1770504

Bühler, Curt F. The Fifteenth Century Book: The Scribes, the Printers, the Decorators. Philadelphia: University of Pennsylvania Press, 1960.

Cashion, Debra Taylor. The Rowland Prayerbook of Nikolaus Glockendon: Manuscript Painting in the Golden Age of Nuremberg. PhD diss., University of California, Berkeley, 1994 (Ann Arbor: UMI, 1994).

Chazelle, Celia. "Christ and the Vision of God: The Biblical Diagrams of the Codex Amiatinus." In The Mind's Eye: Art and Theological Argument in the Middle Ages, 84-111. Edited by Jeffrey F. Hamburger and Anne-Marie Bouché. Princeton: Princeton University Press, 2006.

Chapuis, Julien. Tilman Riemenschneider: Master Sculptor of the Late Middle Ages. Exh. cat. Washington, D.C.: National Gallery of Art, 1999.

Classen, Albrecht. "Heinrich Steinhöwel." In German Writers of the Renaissance and Reformation, 1280-1580, 276-80. Edited by James Hardin and Max Reinhart. Dictionary of Literary Biography, vol. 179. Detroit: Gale Research, 1997.

Conway, William M. The Literary Remains of Albrecht Dürer. Cambridge, UK: University Press, 1889.

Cuneo, Pia F. “The Basilica Cycle of Saint Katherine's Convent: Art and Female Community in Early-Renaissance Augsburg." Women's Art Journal 19, no. 1 (Spring-Summer 1998): 21 25. doi:10.2307/1358650

Dackerman, Susan. Painted Prints: The Revelation of Color. Exh. cat. (Baltimore Museum of Art). University Park: Penn State University Press, 2002.

De Hamel, Christopher. A History of Illuminated Manuscripts. London: Phaidon, 1994.

Dechow, Jon F. Dogma and Mysticism in Early Christianity: Epiphanius of Cyprus and the Legacy of Origen. Macon, GA: Mercer University Press, 1988.

DeFoer, Henri. "Images as Aids for Earning the Indulgences of Rome." In Tributes in Honor of James Marrow: Studies in Painting and Manuscript Illumination of the Late Middle Ages and Renaissance, 163-71. Edited by Jeffrey F. Hamburger and Anne S. Korteweg. Turnhout, Belgium: Brepols, 2006.

Dempster, Germaine. "Chaucer's Manuscript of Petrarch's Version of the Griselda Story." Modern 
Philology 41, no.1 (August 1943): 6-16. doi:10.1086/388598

Dinshaw, Carolyn. Chaucer's Sexual Poetics. Madison: University of Wisconsin Press, 1989.

Dürer, Albrecht. Vier Bücher von Menschlicher Proportion. London: G. M. Wagner, 1970.

Eser, Thomas, and Anja Grebe. Heilige und Hasen: Bücherschätze der Dürerzeit. Exh. cat. Nuremberg: Germanisches Nationalmuseum, 2008.

Farquhar, James Douglas, and Sandra Hindman. Pen to Press: Illustrated Manuscripts and Printed Books in the First Century of Printing. Exh. cat. (University of Maryland Art Dept. Gallery). College Park: University of Maryland Press, 1977.

Flood, John L. "Niklas von Wyle." In German Writers of the Renaissance and Reformation, 12801580, 332-37. Edited by James Hardin and Max Reinhart. Dictionary of Literary Biography, vol. 179. Detroit: Gale Research, 1997.

Gärtner, Magdalene. Römische Basiliken in Augsburg: Nonnenfrömmigkeit und Malerei um 1500. Schwäbische Geschitchtsquellen und Forschungen 23. Augsburg: Wissner, 2002.

Grebe, Anja. "Ein Gebetbuch aus Nürnberg im Germanischen Nationalmuseum und das Frühwerk von Nikolaus Glockendon.” Anzeiger des Germanischen Nationalmuseums (2005), 97--120.

Hamburger, Jeffrey F. The Visual and the Visionary: Art and Spirituality in Late Medieval Germany. Cambridge, MA: Zone Books, 1998.

Hamburger, Jeffrey, and Anne-Marie Bouché. The Mind`s Eye: Art and Theological Argument in the Middle Ages. Princeton: Princeton University Press, 2006.

Hess, Ursula. Heinrich Steinhöwels 'Griseldis': Studien zur Text-und Überlieferungsgeschichte einer frühhumanistischen Prosanovelle.Munich: C. H. Beck, 1975.

Horst, Kurt van der, William Noel, and Wilhelmina C. M. Wüstefeld. The Utrecht Psalter in Medieval Art: Picturing the Psalms of David. Exh. cat. (Museum Catharijneconvent, Utrecht). Westrenen, The Netherlands: Hes, 1996.

Hutchison, Jane Campbell. Albrecht Dürer: A Biography. Princeton: Princeton University Press, 1990.

Jones, Mark. Fake? The Art of Deception. Berkeley: University of California Press, 1990.

Kahsnitz, Rainer, ed. Veit Stoss in Nürnberg. Exh. cat. (Germanisches Nationalmuseum). Munich: Deutscher Kunstverlag, 1983.).

Kahsnitz, Rainer, and William D. Wixom. Gothic and Renaissance Art in Nuremberg, 1300-1550. 
Exh. cat. New York: Metropolitan Museum of Art, 1986.

Kapr, Albert. Johann Neudürffer d. f., der grosse Schreibmeister der deutschen Renaissance. Lepizig: Otto Harrassowitz, 1956.

Kapr, Albert. Johannes Gutenberg: The Man and his Invention. Brookfield, VT: Scolar Press, 1996.

Keller, Adelbert, ed. Translationen von Niclas von Wyle. Hildesheim: G. Olms, 1967.

Koerner, Joseph Leo. “Albrecht Dürer, A Sixteenth-Century Influenza." In Albrecht Dürer and His Legacy: The Graphic Work of a Renaissance Artist, 18-38. Exh. cat. (British Museum). Edited by Guilia Bartrum. Princeton: Princeton University Press, 2002.

Koerner, Joseph Leo. The Moment of Self-Portraiture in German Renaissance Art. Chicago: University of Chicago Press, 1996.

König, Eberhard. "The Influence of the Invention of Printing on the Development of German Illumination." In Manuscripts in the Fifty Years after the Invention of Printing, 85-94. Edited by J. B. Trapp. London: Warburg Institute, 1983.

König, Eberhard. "Text und Bild im Gebetbuch in Modena: Die Vorgabe des Autors und die Gestaltung durch Schreiber und Maler." In Das Glockendon-Gebetbuch: Biblioteca Estenbse Universitaria, alpha.U.6.7, 2:97-153. Edited by Regina Cermann. Lucerne: Faksimile Verlag, 1998.

Krautheimer, Richard. "Introduction to an 'Iconography of Medieval Architecture." Journal of the Warburg and Courtauld Institutes 5 (1942): 1-33. doi:10.2307/750446

Kren, Thomas, and Scot McKendrik. Illuminating the Renaissance: The Triumph of Flemish Manuscript Painting in Europe. Exh. cat. Los Angeles: J. Paul Getty Museum, 2003.

Lincoln, Evelyn. The Invention of the Italian Renaissance Printmaker. New Haven: Yale University Press, 2000.

Lochner, G. W. H., ed. Des Johann Neudörfer Schreib- und Rechenmeisters zu Nörnberg Nachrichten von Künstlern und Werkleuten daselbst aus dem Jahre 1547. Vienna: W. Braumüller, 1875.

Lossnitzer, Max. Veit Stoss. Leipzig: J. Zeitler, 1912.

Mango, Cyril. The Art of the Byzantine Empire, 312-1453: Sources and Documents. Toronto: University of Toronto Press, 1986.

Marrow, James H. "A Book of Hours from the Circle of the Master of the Berlin Passion: Note on the Relationship between Fifteenth-century Manuscript Illumination and Printmaking in the Rhenish Lowlands.” Art Bulletin 60 (1978): 590-616. doi:10.2307/3049840 
Marrow, James H. "Nikolaus Glockendon and Simon Bening: German Copies of the Evangelist Portraits in Bening's Stockholm Book of Hours." Nationalmuseum Bulletin, Stockholm 7, no. 2 (1983): 93-101.

Marvin, Miranda. “Copying in Roman Sculpture: The Replica Series." In Retaining the Original: Multiple Originals, Copies, and Reproduction, 29-45. Studies in the History of Art 20. Center for Advanced Study in the Visual Arts Symposium Papers VII. Washington, D.C., National Gallery of Art, 1989.

Marvin, Miranda. "Roman Sculptural Reproductions or Polykleitos: The Sequel." In Sculpture and Its Reproductions, 7-28. Edited by Anthony Hughes and Erich Ranfft. London: Reaktion Books, 1997.

Mende, Matthias, Anna Scherbaum, and Rainer Schoch. Die Drei Grossen Bücher. Nördlingen, Germany: Alfons Uhl, 2001.

Merkl, Ulrich. Buchmalerei in Bayern in der ersten Hälfte des 16. Jahrhunderts: Spätblüte und Endzeit einer Gattung. Regensburg: Schnell \& Steiner, 1999.

Merkl, Ulrich. "Nikolaus Glockendons Leben und Werk.” In Das Glockendon Gebetbuch: Biblioteca Estenbse Universitaria, alpha.U.6.7, 2:47-74. Edited by Regina Cermann. Lucerne: Faksimile Verlag, 1998.

Miedema, Nine. "Following the Footsteps of Christ: Pilgrimage and Passion Devotion.” In The Broken Body: Passion Devotion in Late Medieval Culture, 73-92. Edited by A. A. MacDonald, H. N. B. Ridderbos, and R. M. Schlusemann. Groningen: Egbert Forsten, 1998.

Morall, Eric John. Aeneas Silvius Piccolomini (Pius II) and Niklas von Wyle: The Tale of Two Lovers Eurialus and Lucretia. Amsterdam: Rodopi, 1988.

Panofsky, Erwin. The Life and Art of Albrecht Dürer. Princeton: Princeton University Press, 1971.

Parshall, Peter. "Imago Contrafacta: Images and Facts in the Northern Renaissance." Art History 16, no. 4 (December 1993): 554-79.

Patterson, Lee. “On the Margin: Postmodernism, Ironic History, and Medieval Studies." Speculum 65, no. 1 (January 1990): 87-108. doi:10.2307/2864473

Peters, Jan S. "Early Drawings by Augustin Hirschvogel." Master Drawings 17, no. 4 (Winter 1979): 359-92, 429-35.

Pizan, Christine de. The Book of the City of Ladies. Translated by Earl Jeffrey Richards. New York, Persea Books, 1982.

Pon, Lisa. Raphael, Dürer, and Marcantonio Raimondi: Copying and the Italian Renaissance Print. 
New Haven: Yale University Press, 2004.

Price, David Hotchkiss. Albrecht Dürer's Renaissance: Humanism, Reformation, and the Art of Faith. Ann Arbor: University of Michigan Press, 2003.

Pyhrr, Stuart W. Donald J. LaRocca, and Dirk H. Breiding. The Armored Horse in Europe, 14801620. Exh. cat. New York: Metropolitan Museum of Art, 2005.

Redlich, Paul. Der Cardinal Albrecht von Brandenburg und das neue Stift zu Halle, 1520-1541. Mainz: Franz Kirchheim, 1900.

Reinhart, Max, ed. Early Modern German Literature, 1350-1700. Rochester, NY: Camden House, 2007.

Ridderbos, Bernard. “The Man of Sorrows: Pictorial Images and Metaphorical Statements.” In The Broken Body: Passion Devotion in Late-Medieval Culture, 145-81. Edited by A. A. MacDonald, H. N. B. Ridderbos, and R. M. Schlusemann.. Groningen: Egbert Forsten, 1998.

Rosenberg, Marc. Der goldschmiede Merkzeichen. 4 vols. Frankfurt: Frankfurter Verlags-Anstalt, 1922-28.

Rowlands, John, and Giulia Bartrum. Drawings by German Artists and Artists from German-Speaking Regions of Europe in the Department of Prints and Drawings in the British Museum. London: British Museum Press, 1993.

Rupprich, Hans. Dürer Schriftlicher Nachlass. 3 vols. Berlin: Deutscher Verein für Kunstwissenschaft, 1956.

Schauerte, Thomas, and Andreas Tacke. Der Kardinal: Albrecht von Brandenburg, Renaissancefürst und Mäzen. 2 vols. Exh. cat. (Stiftung Moritzburg). Regensburg, Schnell \& Steiner, 2006.

Schiller, Gertrud. Iconography of Christian Art. 2 vols. Greenwich, CT: New York Graphic Society, 1972.

Shailor, Barbara. The Medieval Book. Exh. cat. (Beinecke Library). New Haven: Yale University, 1988.

Shoemaker, Innis H. The Engravings of Marcantonio Raimondi. Exh. cat. Lawrence, KS: Spencer Museum of Art, 1981.

Silver, Larry. Marketing Maximilian: The Visual Ideology of a Holy Roman Emperor. Princeton: Princeton University Press, 2008.

Simson, Otto von. The Gothic Cathedral: Origins of Gothic Architecture and the Medieval Concept of Order. Princeton: Princeton University Press, 1974. 
Smith, Jeffrey Chipps. German Sculpture of the Later Renaissance, c. 1520-1580: Art in an Age of Uncertainty. Princeton: Princeton University Press, 1994.

Smith, Jeffrey Chipps. Nuremberg: A Renaissance City, 1500--1618. Exh. cat. (Huntington Gallery, University of Texas). Austin: University of Texas Press, 1983.

Smith, Pamela H. The Body of the Artisan: Art and Experience in the Scientific Revolution. Chicago: University of Chicago Press, 2004.

Smith, Pamela H., and Tony Beentjes. "Nature and Art, Making and Knowing: Reconstructing Sixteenth-Century Life-Casting Techniques."Renaissance Quarterly 63 (Spring 2010): 128-

79. doi:10.1086/652535

Smith, Webster. The Farnese Hours. New York: George Braziller, 1976.

Snyder, James. Medieval Art: Painting, Sculpture, Architecture, 4th-14th Century. New York: Harry N. Abrams, 1989.

Spear, Richard E. "Notes on Renaissance and Baroque Originals and Originality." In Retaining the Original: Multiple Originals, Copies, and Reproductions, 97-99. Studies in the History of Art 20.

Center for Advanced Study in the Visual Arts Symposium Papers VII. Washington, D.C., National Gallery of Art, 1989.

Steinmann, Ulrich. "Das Andachts-Gebetbuch vom Leiden Christi des Cardinals Albrecht von Brandenburg." Aachener Kunstblätter 29 (1964): 139-77.

Stewart, Alison G. Before Bruegel: Sebald Beham and the Origins of Peasant Festival Imagery. Burlington, VT: Ashgate, 2008.

Stewart, Alison G. The First Peasant Festivals': Eleven Woodcuts Produced in Reformation Nuremberg by Barthel and Sebald Beham and Erhard Schön, ca. 1524-1535. PhD diss. Columbia University, 1986 (Ann Arbor, UMI: 1986).

Strauss, Gerald. Nuremberg in the Sixteenth Century. Bloomington: Indiana University Press, 1976.

Strieder, Peter. Meister um Albrecht Dürer. Exh. cat. Nuremberg, Germanisches Nationalmuseum, 1961.

Suckale, Robert. “Die Zeit der Gotik: Die Regensburger Buchmalerei von 1250 bis 1350.” In Regensburger Buchmalerei: Von frühkarolingischer Zeit bis zum Ausgang des Mittelalters, 79-92. Exh. cat. (Bayerische Staatsbibliothek and Museen der Stadt Regensburg). Edited by Florentine Mütherich and Karl Dachs. Munich: Prestel-Verlag, 1987. 
Tasioulas, J. A. "Between Doctrine and Domesticity: The Portrayal of Mary in the N-Town Plays." In Medieval Women and their Communities, 222-45. Edited by Diane Watt. Toronto: University of Toronto Press, 1997.

Thoss, Dagmar. Gebetbuch für Kardinal Albrecht von Brandenburg: Gabriel Glockendon, Nürnberg 1536/37. Münster: Biblioteca Rara, 2008.

Urch, Katharina, and Karin Schneider. Gebetbuch von Nikolaus Glockendon für Jakob Welser den flteren. Patrimonia 70. Munich: KulturStiftung der Lander, 1993.

Vasari, Giorgio. Lives of the Most Eminent Painters, Sculptors, and Architects. 10 vols. Translated by Gaston du C. DeVere. London: Macmillan, 1912-14.

Vogt, Christine. Das Druckgraphische Bild nach Vorlagen Albrecht Dürers (1471-1528). Munich: Deutscher Kunstverlag, 2008.

Waldman, Emil. Die Nürnberger Kleinmeister. Leipzig: Klinkhardt \& Biermann, 1910.

Recommended Citation:

Debra Taylor Cashion, "The Art of Nikolaus Glockendon: Imitation and Originality in the Art of Renaissance Germany," JHNA 2:1-2 (2010), D0I: 10.5092/jhna.2010.2.1.2 